\title{
Valladolid, el Bto. Alonso de Orozco y el convento de San Aguistín
}

\section{UNA IGLESIA EN RUINAS EN EL PASEO DE ISABEL LA CATÓLICA}

Al tiempo de pergeñar y escribir, más tarde, estas líneas, me acerqué hasta el hermoso y amplio Paseo de Isabel la Católica en una plácida tarde de otoño, para contemplar una vez más -no sin cierto dolor de mi alma- la inmensa mole de piedra blanca, de sillería, finamente labrada, del más puro estilo herreriano, y que un día formara los gruesos muros, el ábside y la fachada de la iglesia de San Agustín de Valladolid, donde predicara aquel santo limosnero y padre de los pobres, Fray Tomás de Villanueva, y a quien escuchara con gran consuelo y alegría espiritual el emperador Carlos V, mientras ambos vivieran -el César siempre de paso, siempre en camino--, en la vieja e histórica ciudad del Conde Ansúrez; y donde también residieran, predicaran la palabra y escribieran algunas de sus obras, como hemos de ver luego, los insignes agustinos beato Alonso de Orozco y Fray Luis de León.

Es lo único que queda de aquel magnífico templo: paredes laterales con sus contrafuertes, fachada renacentista de la tercera etapa de este arte en España, y esbelto ábside, también herreriano, que fue terminado de hacer por el arquitecto don Baltasar Álvarez ${ }^{1}$, "amigo de grandes empresas y eminente en su profesión".

"Fundado en 1407 gracias al Condestable de Castilla Ruy López de Dávalos -leemos en una interesante Guía de Valladolid-, que donó generosamente los terrenos, la primitiva iglesia del convento fue sustituida por otra que se inició a mediados del siglo XVI, realizándose entonces la excelente cabecera y crucero del templo, así como las dos primeras capillas del cuerpo de la iglesia. Las obras se prosiguieron en 1619, utilizando trazas facilitadas

1. GonZález García-VAlladolid, C., Valladolid, sus Recuerdos y Grandezas, Valladolid 1900, vol. I, p. 85 . 
por el arquitecto Diego de Praves, bajo las cuales se concluiría su fachada principal, en la que campean las armas de los condes de Villamediana que ejercían el patronato del convento desde el 1606. Junto al templo, se construyó el desaparecido colegio de San Gabriel, perteneciente a la misma Orden agustina ${ }^{2}$.

“El templo, en ruinas desde los primeros años del presente siglo, consta de una nave central, con cinco capillas entre contrafuertes, mostrando su cabecera rasgos renacentistas.

La fachada, de buena cantería, consta de dos cuerpos y tiene un desequilibrio de proporciones plenamente manieristas. Su lenguaje sigue siendo herreriano, reduciéndose sus motivos ornamentales a formas puramente geométricas".

Dicha fachada manierista es posterior a la fábrica del templo, y fue rematada ya a finales del siglo XVII. Es de orden dórico y ocupa su centro el pórtico, circular, el cual contiene la puerta de entrada rectangular, de líneas perfectas y, sobre ella, bajo el punto medio del arco, se halla un nicho con la estatua de san Agustín. Una cornisa bien proporcionada sirve de base al segundo cuerpo, que está formado por cuatro pilastras perpendiculares a las del primero, pero de menor altura. En su parte media, hay una lucerna de correcto dibujo, y a sus lados, escudos con las armas de los mencionados fundadores. La fachada remata con un lindo ático, en el que se encuentra el escudo de la Orden de san Agustín ${ }^{3}$.

En el interior de lo que fuera magnífica iglesia herreriana, podemos ver todavía las huellas de la capilla mayor, dedicada a los mismos fundadores y mecenas del monasterio e iglesia. Del mismo estilo dórico, está sostenida por cuatro soberbias columnas estriadas, una a cada ángulo. En ella dejaron su linaje -y en ella reposan- los condes de Villamediana, de apellido Tasis, descendientes de una noble familia milanesa: los antiguos Turrianos.

Don Juan de Tasis fue el primer conde de Villamediana y, también, el primer patrono de dicha capilla mayor. Ayudó a la dotación de este patronato don Felipe de Tasis, hermano del anterior y arzobispo de Granada.

Muerto sin sucesión el hijo de don Juan de Tasis, "heredó su estado y oficio de Correo Mayor y el patronazgo de la capilla mayor de San Agustín de Valladolid don Íñigo Vélez Ladrón de Guevara, señor de Salanillas y de doña Catalina Vélez de Guevara, condesa de Oñate, nieto de don Pedro Vélez de Guevara y de doña Mariana de Tasis, hermana del primer conde de

2. Urrea, J., Guía Histórico-Artística de la Ciudad de Valladolid. Ed. Caja de Ahorros Popular de Valladolid. Imp. Sever-Cuesta, Valladolid 1982, p. 67.

3. GonZÁlez GARCÁA-VAlladolid, C., o.c., p. 86. 
Villamediana, hijo de Raimundo de Tasis, Correo Mayor de España, y de doña Catalina de Acuña, su mujer, según nos cuenta el historiador agustino Tomás de Herrera ${ }^{4}$.

Jesús Urrea nos dice que la iglesia tuvo cinco capillas; pero no es del todo exacto, ya que primitivamente tuvo hasta seis laterales, dentro de la enorme nave de forma de cruz latina, más otras dos a los lados del crucero: la del Evangelio, fundada por don Francisco de Rivadeneira, Caballero de la Orden de Santiago y Registrador de Valladolid, bajo la advocación de Santiago el Mayor; y la del lado de la epístola, fundación del rico y opulento indiano Fabio Nelli de Espinosa, cuyo palacio contiene hoy el Museo Arqueológico de nuestra ciudad, y cuyo altar contenía un magnífico lienzo que representaba la Anunciación, titula ${ }_{\star}$ de la capilla, obra del pintor vallisoletano Gregorio Martínez, que se conserva actualmente en el Museo de la Pasión; en torno a este cuadro había primorosas pinturas al temple en los muros, del mismo artista y poco menos que desconocido pintor castellano ${ }^{5}$, de finales del siglo XVI, rafaelesco y ya manierista.

De aquella gran fábrica, de todo aquello que fue uno de los templos más bellos, significativos y frecuentados por los fieles de nuestra ciudad, donde estuvo radicada durante muchos años la Cofradía penitencial de Jesús Nazareno, solamente quedan los muros señalados arriba y la nostalgia de los que, de vez en cuando, los contemplamos.

\section{UNo de los CUATro grandes conventos de la Provincia DE CAstilla}

Eso nos dicen que fue, en tiempos pasados, el convento de San Agustín de Valladolid: uno de los cuatro grandes de la Provincia de Castilla, fundado -como queda reseñado arriba- por el condestable don Ruiz López de Ávalos, o Dávalos, el cual, junto con su esposa doña Elvira de Guevara, hizo donación a los agustinos de unas casas que habían sido propiedad de doña Catalina, esposa del rey Enrique III "El Doliente".

Refiriéndose a esta fundación, el historiador Tomás de Herrera, ilustre agustino nacido en Medina del Campo el 11 de diciembre de 1585 y autor de dos obras fundamentales para la historia de los agustinos en España: el $\mathrm{Al}$ -

4. Herrera, T. de, Historia del convento de San Agustín de Salamanca. Imp. Gregorio Rodríguez, Madrid 1652, p. 180.

5. A este pintor vallisoletano, Gregorio Martínez, lo cita Jesús Urrea en su Guía HistóricoArtística de Valladolid, l.c., p. 105. 
phabetum Augustinianum ${ }^{6}$, y la citada Historia del Convento de San Agustín de Salamanca ${ }^{7}$, al tiempo que corrige y aclara algunos puntos oscuros que encuentra en el cronista Jerónimo Román, autor de las Centurias, el cual da como fecha segura de fundación el año 1410, cometiendo, además, algunos errores de bulto en cuanto a los bienhechores que donaron la propiedad de las casas que fueron palacio real, declara que visitó el convento el año 1640 y en él pudo comprobar la escritura de donación, que dice cómo "en dicho día (13 de junio de 1407), mes y año, el doctor Fray Aparicio de Burgos, prior de Toledo ${ }^{8}$, y Fray Pedro de San Gil de Burgos, prior de Dueñas, tomaron posesión de unas casas, que les había dado el condestable D. Rui López Dávalos, y su segunda mujer, doña Elvira de Guevara. Estaban las casas en un sitio llamado de el Arrehoyo, y después vinieron a ser de la reina doña Caterina, mujer del rey don Enrique el Tercero, la cual murió en Valladolid, jueves, a 2 de junio de 1418. La reina las dio al dicho condestable, camarero, y adelantado mayor del reino de Murcia; y el rey don Enrique su marido a 21 de mayo de 1398, confirmó la donación, y añadió un huerto, y otras casas, que había comprado de un ciudadano de Valladolid" 9.

A esta señora doña Elvira de Guevara se la consideró de siempre fundadora del convento, por haber donado también sus casas, como lo hiciera su esposo el condestable Ruy López Dávạlos. Así se expresa Galíndez de Carvajal en sus Adiciones a los Claros Varones de Fernán Pérez de Guzmán, donde, refiriéndose a la fundación de este monasterio agustiniano, dice lo siguiente: "La dicha doña Elvira de Guevara, mujer segunda de dicho Condestable Don Rui López Dávalos, fundó en sus propias casas el Monasterio de San Agustín, que hoy está en la villa de Valladolid, donde se sepultó; el cual es junto a la puerta del río, e como aquí dice Fernán Pérez" ${ }^{10}$.

6. Herrera, T., Alphabetum Augustinianum, Matriti 1644, 2 vols.

7. Cf. nota n. 4.

8. El P. Herrera, en el capítulo que dedica a la fundación del convento de San Agustín de Toledo, dice de Fray Aparicio de Burgos lo siguiente: "El año de 1407 era prior el P. M. Fr. Aparicio, que después fue Provincial. En ese año tomó la posesión del convento de San Agustín de Valladolid, que fundó Rui López Dávalos, Condestable de Castilla" (Cf. HerrerA, T. de, Historia del convento de San Agustín de Salamanca, l.c., p. 190).

9. HerRera, T. de, o.c., p. 177.

10. Fernán Pérez de Guzmán, escritor español y señor de Batres, bisabuelo de Garcilaso, tío del marqués de Santillana y sobrino del canciller López de Ayala, vivió en tiempos de Enrique III, denominado "El Doliente". Desempeñó el cargo de embajador en la corte de Aragón. Con la subida al trono de Juan II, militó en el bando de los enemigos de don Álvaro de Luna, y a esta enemistad se debe quizá el que en 1431 se le negara el premio debido por su acción en la batalla de La Higuera, en la que salvó la vida al capitán de la mesnada, el señor de Hita. Caído en desgracia del monarca y del privado, fue condenado a prisión. Libre y desengañado de las intrigas de la corte, se retiró a su señorío de Batres, donde permaneció dedicado al estudio y las letras hasta su muerte, que debió ocurrir el año 1460. 
Según esta relación del doctor Galíndez, Herrera afirma que bien podemos decir que el sepulcro de dicha señora doña Elvira de Guevara se encuentra en dicha iglesia; "pero el tiempo ha borrado la memoria, de manera que podemos añadir -escribe literalmente- que el día de hoy nadie conoce su sepulcro. Raro descuido. Pero mayores maravillas suele causar un largo tiempo" ${ }^{11}$.

$\mathrm{El}$ mismo historiador medinense nos dice que esta buena señora, como refiere Argote de Molina, en la Nobleza de Andalucía ${ }^{12}$, era hija de don Beltrán de Guevara, señor de Oñate, y de su mujer doña Mencía de Ayala, hija de Hernán Pérez de Ayala y doña Elvira de Zavallos.

En cuanto al condestable don Ruy López Dávalos, o de Ávalos, el citado cronista dice que fue un gran bienhechor de la Orden de San Agustín, pues no contento con la fundación del convento de Valladolid, compró en la villa de Dueñas unas casas a un rico indiano, y las donó al monasterio de aquella villa, para su ensanche y engrandecimiento. Consta por los Registros Generalicios del Rdmo. Agustín Romano ${ }^{13}$ que en 1426, dos años antes de su muerte, acaecida en la ciudad de Valencia el 6 de enero de 1428, trató de fundar otro convento para la misma Orden en "una tierra suya del Reino de Castilla, para que en él se guarde la forma de la Observancia Regular" ${ }^{14}$.

El mismo Herrera añade, después de traducir al castellano el texto latino, que no tenemos rastro de que estos buenos deseos del Condestable llegasen a efecto; pero la buena voluntad merece ser estimada y agradecida ${ }^{15}$. Por

11. Herrera, T. de, Historia del convento de San Agustín, l.c., p. 177.

12. Argote de Molina, G., Nobleza de Andalucía, 1588, lib. 2, cap. 164, fol. 287.

13. El Rvmo. Agustín Romano, se conoce dentro de la Orden por el nombre de Fray Agustín Favaroni. Se ignora el lugar de nacimiento. Ambrosio Corano dice de él que fue otro Agustín, tanto por las obras que escribió, como por su saber teológico. En el 1384, lo encontramos en el convento de Bolonia realizando sus estudios eclesiásticos. Dos años más tarde, estaba de residencia en el de Florencia, para volver de nuevo al de Bolonia.

Conseguido el magisterio, fue nombrado Provincial en 1407. En el Capítulo de 1419, fue electo prior General, cargo que regentó por espacio de doce años, promoviendo la observancia religiosa.

En el año 1431 el papa Eugenio IV le elevó a la silla episcopal de Nazaret (Bari, en Apulia). Perini cita hasta veintisiete tratados escritos por este hijo ilustre de la Orden de San Agustín. (Cf. PERInI, David Aurelius, Bibliographia Augustiniana).

14. El texto del Registro Generalicio, que lleva la fecha del 18 de octubre de 1426, dice así: "Eodem die dedimus aliam similem licentiam Fr. Alfonso de Villoria Baccalaureo Provinciae Hispaniae pro alio loco, quem magnificus Dominus Comestabularius Rodericus Lupix de Dávalos in quadam sua terra Regni castellae construere vult, ut in eo servetur forma observantia Regularis. Quod et nos fieri volentes, conmittimus, eodem volente, ipsum conventum construendum, et suscipiendum dicto Fr. Alfonso, Capellano, suo quode illo post se esse Patronum vult". (Cf. Herrera, T. de, Historia del convento de San Agustín de Salamanca, 1.c., p. 177).

15. Herrera, T. de, 1.c., p. 177. 
lo demás, completando la biografía de este gran mecenas de la Orden Agustiniana, sabemos que don Ruy López Dávalos era de origen andaluz y empezó a distinguirse en el sitio de Benavente, el año 1387. Miembro del consejo de Enrique III, formó en la villa toledana de Illescas, junto con otros magnates, el año 1394 una liga al servicio del "Doliente". Con Juan Hurtado y Diego López de Stúñiga, formó parte del triunvirato que llevaría las riendas del poder. Más tarde, intervino en las negociaciones que acabaron con la huida del conde de Noreña y la subsiguiente toma de Gijón por las fuerzas reales. Pronto pasó a ser el principal miembro del consejo. En 1396 puso fin a importantes banderías de Andalucía, donde al parecer actuó con extraordinaria dureza. En este mismo año, penetró con sus tropas en Portugal, tomando la ciudad de Viseo. Enrique III, de quien era, como hemos visto, gran favorito, le nombró condestable de Castilla, y aunque estuvo desterrado de la corte, el 1402 inició las definitivas negociaciones de paz con el reino de Portugal, las cuales no concluyeron hasta después de la muerte del soberano.

El Doliente le nombró, en su testamento, miembro del consejo de regencia durante la minoría de edad de su hijo Juan II. Posteriormente, fue uno de los árbitros del infante Enrique, tío del rey, y por ello se atrajo las iras y la irreconciliable enemistad de don Álvaro de Luna. Fue entonces cuando tuvo que huir al reino de Aragón en 1422, siendo confiscado su tesoro en la fortaleza de Jódar.

Leíamos antes una frase llena de contenido: "Para que en él se guarde la forma de la Observancia Regular". Efectivamente, en aquellos días del siglo XV, la Iglesia estaba necesitada de una reforma, que sólo se consiguió un siglo más adelante, con el Concilio de Trento. Pero algunas Órdenes Religiosas, sin esperar a que ésta se comenzara en Roma por la Cabeza, iniciaron por su cuenta lo que estaban pidiendo a gritos desde los más ilustres humanistas, hasta las más bajas esferas de la sociedad.

El convento de San Agustín de Valladolid había aceptado de modo definitivo la observancia, que tiempo atrás -el año 1431- había comenzado el venerable Fray Juan de Alarcón, precisamente en otro convento situado no lejos de Valladolid, el de Villanubla, llamado "el convento de los santos", y fundado expresamente para dicha reforma, según consta por la aprobación del citado Padre General, Agustín Romano, con fecha 14 de abril del mismo año 1431. Una observancia regular y una vida más en pobreza y más austera, que abrazaron también los conventos de Arenas de San Pedro, el de Dueñas y el de las monjas agustinas de Madrigal de las Altas Torres.

A partir del año 1495, el convento agustiniano de orillas del Pisuerga salió como de la modorra espiritual en que yacía, y dio comienzo a una vidà nueva, dando preciosos frutos tanto en ciencia, como en virtud. De tal modo, 
que, encariñado con este monasterio Fray Alonso de Burgos, obispo de Palencia y esclarecido religioso de la Orden de Predicadores, le dejó en su testamento, otorgado el día 4 de octubre de 1499, una limosna por los motivos y para los fines que en el mismo se expresan y que reza así: "Otro sí mandamos al monasterio de San Agustín desta dicha villa, que ahora está reformado, e porque mejor puedan servir a Dios Nuestro Señor y estar en su Observancia Regular, setenta y cinco mil maravedís, para reparo del dicho monasterio, e para el mantenimiento e necesidad de los Religiosos dél" ${ }^{16}$.

\section{HIJOS ILUSTRES DEL CONVENTO DE SAN AGUSTÍN DE VALLADOLID}

Antes de detenernos en las tres grandes figuras que son un poco el orgullo del convento de San Agustín de Valladolid: Santo Tomás de Villanueva, Fray Luis de León y el Beato Alonso de Orozco, debemos mencionar como hijos ilustres del mismo al Venerable Juan de Alarcón, cuyo nombre ha salido en páginas anteriores, fundador de la Congregación de la Observancia de España, y que sabemos murió el año 1449.

Manuel Vidal -historiador del convento de San Agustín de Salamancadice de él que "era muy noble por su origen, hijo legítimo de Martín Ruiz de Alarcón, sexto señor de Alarcón y de las villas de Valverde y Talayuelas, y de doña Constanza Díaz, su tercera mujer". Pero no señala el lugar de nacimiento, que Gregorio de Santiago Vela supone fue en la villa conquense de su apellido, es decir, de Alarcón.

Nada se sabe, igualmente, de la fecha en que abrazó la vida religiosa; así como de sus primeros años de conventual. En 1420, lo encontramos en Italia adonde probablemente se dirigió con el fin de continuar sus estudios, toda vez que en los Registros generalicios del Rvdmo. Agustín Romano se lee lo siguiente: "Dimos licencia a Fr. Juan de Alarcón, el cual por el Capítulo general de Aste (que se celebró en 1419) fue promovido para la lectura de Biblia en el estudio y convento de Florencia, para que pueda ir allá e incorporarse en aquella Universidad y proseguir su lectura... También otra para que pueda ir a Roma" ${ }^{17}$.

Herrera, que le incluye entre los hijos de hábito del convento de Valladolid, si bien no cuenta con sólidos fundamentos para ello, supone igualmente que debió licenciarse en Teología en la mencionada Universidad de Florencia. Es posible que la idea de reformar los conventos de España la tuviera

16. Lopez, J., Historia de la Orden de Predicadores. Parte III, lib. $3^{\circ}$, c. 84.

17. Santiago Vela, G. de, Ensayo de una Biblioteca Iberoamericana, Imp. Asilo de Huérfanos del S. C. de Jesús, Madrid 1913, vol. I, p. 71. 
ya desde estos mismos momentos de su vida, tal vez movido por el ejemplo que le daban los agustinos de Italia, los cuales habían entrado ya por la reforma.

Con este pensamiento y con la aprobación expresa del superior General de la Orden, regresó a España y fundó enseguida -año de 1431- el convento de Villanubla, como hemos visto arriba, cercano a la ciudad de Valladolid, siendo este monasterio el primero donde se estableció el nuevo método de vida, que más tarde abrazaron otros.

El día 3 de octubre de 1439, con las patentes del nuevo superior General, Rvmo. P. Gerardo de Rímini ${ }^{18}$, y con la bula del papa Eugenio IV ${ }^{19}$, confirmando la naciente Congregación, Fray Juan de Alarcón celebró el primer capítulo de la misma, en el que fueron aprobadas las Actas o Estatutos por los que habrían de regirse en el futuro cuantos conventos abrazasen la nueva regla ${ }^{20}$.

Jerónimo Román afirma de este religioso que fue "gran teólogo y muy privado del rey don Juan el Segundo ${ }^{21}$, a cuya protección y acaso a la del Condestable don Álvaro de Luna se debió el que, durante aquel reinado, tomara tanto incremento la Congregación de la Observancia. Pruebas recibió de dicho monarca y muy señaladas en las repetidas donaciones de tierras

18. El Rdmo. P. Gerardo de Rímini gobernó la Orden de San Agustín de 1431 a 1443. Este gobierno se distinguió por la promoción y aliento a una vuelta de la más estricta observancia en las Órdenes religiosas, que habían entrado en una penosa decadencia, después de los lamentables efectos del Cisma de Occidente, y a base de la fundación, o fundaciones, de las que se llamaron Congregaciones de la Observancia en Italia, Alemania y en España; aquí debida a la actividad desplegada por Fray Juan de Alarcón.

19. El papa Eugenio IV llevó el timón de la Iglesia desde el año 1431 al 1447. Era sobrino de Gregorio XII. Primeramente, fue monje agustino, más tarde le nombraron obispo de Siena, cardenal en 1408. Siendo príncipe de la Iglesia, reconoció a Martín V y fue nombrado legado para la Marca de Ancona en 1420.

Elegido papa, hubo de hacer frente a un nuevo cisma, promovido por los miembros del Concilio de Basilea, que se quedaron en esta ciudad, cuando el Papa lo trasladó a la ciudad de Ferrara y después a Florencia, y depusieron a Eurgenio IV, oponiéndole al antipapa Félix V. Hombre culto y amante de las letras, encargó varios trabajos a Fr. Angélico, siendo el primer romano Pontífice que favoreció la corriente renacentista.

20. Dichas Actas, debidas indudablemente al Vble. Juan de Alarcón, y en número de Cuarenta y seis, se conservan cuidadosamente copiadas por el P. Juan de Sevilla en un códice de finales del siglo XV, y fueron publicadas por el P. Tirso López en Analecta Augustiniana, vol. III, p. 60 y ss.

21. Juan II de Castilla, padre de Isabel la Cátolica, había nacido en Toro en 1406 y muerto en Valladolid en 1454. Era hijo de Enrique III y de Catalina de Lancáster. La prematura muerte de su padre (en 1406), dio paso a una etapa de minoridad, que concluyó al ser declarado mayor de edad en 1419. Casó muy joven con María, hija de Fernando I de Aragón, y de este matrimonio nació el príncipe Enrique, más tarde, Enrique IV. De su segundo enlace con Isabel de Portugal nacieron los príncipes Alfonso, que murió muy joven, y la citada Isabel, luego reina de Castilla. 
a los conventos y en la concesión de privilegios a los mismos, entonces tan necesarios para que la reforma prosperara.

Algo por la nobleza de sangre y mucho por la virtud que en él resplandecía -escribe Gregorio de Santiago Vela-, el Ven. Alarcón debió ser uno de aquellos religiosos que con tanta frecuencia se interponían entre los distintos bandos de los nobles que en aquella época se disputaban la privanza del rey, evitando con el peso de su influencia y prestigio el derramamiento de sangre en las continuas luchas y turbulencias que tanto agitaron aquel reinado ${ }^{22}$.

No se sabe con certeza la fecha de su muerte, que los historiadores se aventuran a poner en 1451, basados en que, en este año, fue elegido para sucederle en el cargo de Vicario General el P. Juan de Montelongo. Lo que sí se sabe es que sus virtudes fueron muy celebradas ya en su tiempo, hasta el punto de que algunos de sus biógrafos le incluyen en el número de los Beatos de la Orden.

Otro de los hijos ilustres de este convento agustiniano de Valladolid fue Fray Enrique Enríquez, "descendiente de la Casa Real de Castilla, hijo de don Martín Enríquez, marqués de Alcañices, virrey de México y del Perú ${ }^{23}$, y de doña María Manrique, hija de los marqueses de Aguilar" ${ }^{24}$.

Vela, que sigue de cerca a los historiadores del convento de San Agustín de Salamanca, declara que profesó en el monasterio de su ciudad natal, Valladolid, el 25 de abril de 1574, en manos del P. Gabriel Pinelo, provincial más tarde de Castilla ${ }^{25}$, el cual era natural también de esta misma ciudad, aunque profesó en el convento de Salamanca y del que un contemporáneo suyo -Juan González de Critana- dice que era "famoso predicador en la corte del rey Felipe II, gran escriturario, y su consejo fue siempre muy estimado en los consejos reales" ${ }^{26}$.

22. Santiago Vela, G. de, Ensayo de una Biblioteca Iberoamericana, vol. I., p. 72.

23. Martín Enríquez de Almansa, que vivió en la segunda mitad del siglo XVI, fue el cuarto virrey de Nueva España, desde 1568 al 1580. Combatió duramente a los indios huachiles, que habían realizado incursiones en algunos lugares de las tierras conquistadas por los españoles, fundando los fuertes de San Felipe, Ojuelo y Portezuelos.

Durante su gobierno, se estableció formalmente la Inquisición. Posteriormente fue virrey del Perú, de 1581 a 1583, en que dio posesión al correo mayor de las Indias, nombrado por Felipe II, e instaló en el virreinato el servicio postal.

24. Herrera, T. de, Historia del convento de San Agustín de Salamanca, 1.c., p. 179.

25. El P. Gabriel Pinelo era también natural de Valladolid.

26. Juan González de Critana había nacido en Villarrubia, provincia de Toledo, teniendo por padres a Fernando de Soria y Ana Lupesia. Vistió el hábito agustiniano en el convento de San Felipe el Real de Madrid, recibiéndole el P. Veracruz, como él mismo lo expresa, e hizo su profesión religiosa el día 26 de mayo de 1573.

Gregorio de Santiago Vela supone que debió hacer los estudios en Alcalá y Salamanca, donde tuvo por maestros a los PP. Alfonso de Villanueva y Diego de Tapia. Se llama también 
Dedicado Fray Enrique Enríquez por los superiores a los estudios eclesiásticos, llegó a ser Maestro en Teología, facultad que explicó a los alumnos de la comunidad agustiniana de Sevilla y Alcalá. Fue también prior de los conventos de Valladolid y de San Felipe el Real, de Madrid. Elegido provincial en el Capítulo celebrado en el mes de mayo de 1601, poco tiempo después, por fallecimiento de su tío, el obispo de Osma, D. Fray Pedro de Rojas, fue nombrado sucesor suyo de esta diócesis, de la que tomó posesión el día 13 de enero de 1603 .

Los que conozcan de cerca la villa burgalesa de Peñaranda de Duero, recordarán sin duda el convento de San José, de carmelitas descalzas, y que fue fundado por este generoso mecenas. Como recordarán, igualmente, la iglesia parroquial de Santa Ana, convertida en colegiata por licencia otorgada por este prelado español a los condes de Miranda y duques de Peñaranda, cuyo espléndido palacio plateresco está situado en la misma plaza de la villa donde se encuentra ubicada dicha iglesia.

Valladolid, por estos días, se había convertido en la corte del ya decadente imperio español. En Valladolid nació el príncipe don Felipe, después rey de España y IV de su nombre y a su bautizo asistió Fray Enrique Enríquez en calidad de grande de España y como descendiente de la Casa Real de Castilla.

Si nos acercamos ahora a la histórica villa de Osma, para contemplar su hermosa catedral del más puro estilo gótico del siglo XIII, podremos ver aún hoy un arco de piedra de sillería, que se halla sobre la puerta principal que da a la antigua plaza, con un gran terrado. En el centro del mismo, se ve un escudo de armas, formado en su parte superior por dos castillos en campo de gules y el corazón simbólico de San Agustín en el medio, con el epígrafe agustiniano, en latín: "Cor meum charitate tua sagitaveras tu, Domine", que traducido al castellano, suena así: "Habías asaetado nuestro corazón con tu caridad, Señor" 27; y en la parte inferior, un león rampante coronado, mirando a la derecha, en campo de plata. Es el escudo de armas de nuestro obispo agustino, que fue quien levantó dicho arco.

Los biógrafos, al tiempo de referirse a la visita pastoral que hizo por toda la diócesis, dan a entender que "tuvo bastante que padecer" ${ }^{28}$.

discípulo de Fray Luis de León, tal vez por haber oído algunas lecciones suyas en las aulas salmantinas, aunque no debieron ser muchas, y éstas después de 1578. Figura en el convento de Valladolid desde el 1596 hasta el 1607 con algunas interrupciones. Nicolás Antonio pone su fallecimiento en San Felipe el Real en fecha ignorada.

27. SAN Agustin, confesiones, lib. IX, cap. 2, n. 3. Edición de la BAC, Madrid 1986, p. 273.

28. Santiago Vela, G. de, Ensayo de una Biblioteca Iberoamericana, vol. II, 1.c., p. 179. 
El año 1609 fue presentado para la silla episcopal de Cuenca, a la que parece renunció, sin que se sepan los motivos. Más tarde, fue preconizado arzobispo de Granada, pero antes de recibirse las bulas, quedó vacante la sede de Plasencia y Fray Enríquez fue trasladado a la misma, tomando posesión el día 28 de agosto de 1610.

En esta noble ciudad cacereña permaneció hasta el 22 de enero nuestro ejemplar prelado, fecha en que murió, con más de setenta años de edad.

Pero sin duda que una de las grandes figuras que honraron con su presencia el convento agustiniano de la ciudad del Pisuerga fue Fray Agustín Antolínez, lumbrera de la Orden, e hijo benemérito de nuestra ciudad, el cual bien se merece este recuerdo y que sea más conocido siquiera entre los que se precian de conocerla, intelectuales o investigadores de la misma.

Fray Agustín Antolínez vio la luz primera el día 16 de diciembre del año 1554. Era hijo de Galaaz Antolínez de Burgos y de doña Catalina Alfonso de Saavedra, de ilustre prosapia castellana. Profesó en el convento de San Agustín de su ciudad natal el día 5 de junio de 1571, cuando contaba los diecisiete de su edad; si bien algunos cronistas la retrotaen al 28 de mayo del mismo año ${ }^{29}$.

Eminente en virtud y ciencia, ocupó primeramente la cátedra de Prima de la Universidad de Valladolid, pasando luego a la de Salamanca, donde conquistó un prestigio de varón sabio y prudente, buen teólogo, amigo de hablar y tratar asuntos de Sagrada Escritura, a la que se mostró siempre muy aficionado.

El P. Antolínez se convirtió más tarde en consejero de los Grandes del reino y en el Maestro de cuantos acudían a su sabio consejo. Regentó, también, las cátedras de Santo Tomás, Durando, Escritura... El rey de España, Felipe IV, quiso nombrarle en 1621 su Predicador; pero el humilde religioso no quiso aceptar tan hoñorífico cargo. Poco tiempo después, en 1622, fue propuesto para la silla episcopal de Ciudad Rodrigo, pasando enseguida a la sede de Santiago de Compostela, donde murió el 19 de junio de 1626.

En honor de este hijo preclaro de la Orden de San Agustín, nada mejor que repetir las palabras que escribió, a raíz de su muerte, uno de los biógrafos: "El hábito que sacó del claustro, ese llevó a Ciudad Rodrigo, y ese mismo usó en su Arzobispado. El ajuar de palacio se componía de lo más preciso, y todo sencillo y llano. Visitóle el Señor con una enfermedad muy trabajosa, de la cual quedó muy mal del estómago, y todavía flaco y sin fuerzas, determinó emprender la visita, contra el parecer de los que le trataban, 
que le amaban entrañablemente. Parece ser que, al tiempo de morir, atormentado por la sed, pidió un vaso de agua; pero, reaccionando luego, tomó el vaso en sus trémulas manos y fijos los ojos en una imagen de Cristo Crucificado, exclamó: "Vos, Señor, sabéis que de cuanto he tenido, os he hecho donación. Ahora me queda este vaso de agua que gustosamente os ofrezco en reverencia de vuestra sed. La mía quiero padecer con Vos, y quiero igualmente padecer cualquier tormento y desamparo a imitación vuestra" "30. Y se abstuvo de beber el vaso de agua, aunque bien lo deseaba y necesitaba.

Había sido consagrado obispo de Ciudad Rodrigo en la sacristía del convento de San Felipe el Real de Madrid, y en cuanto estuvo en su diócesis, "comenzó a ejercer el oficio de padre cariñoso, cuyo corazón rebosaba dulcedumbre y misericordia. Y fue tan ingenioso en arbitrar medios con que poder socorrer a los necesitados, que ni aun de santo Tomás de Villanueva se leen algunos que el Ilmo. Antolínez practicó y de los cuales hablan sus biógrafos con los encomios que es de suponer" ${ }^{31}$.

El P. Antolínez tuvo la suerte de conocer y tratar personalmente a maestros de la talla de Juan de Guevara, Luis de León, Pedro de Aragón, Beato Alonso de Orozco y Alfonso de Mendoza, a los que no les fue en zaga en cuanto a éxitos y triunfos se refiere, opositando a cátedras en la Universidad de Valladolid y de Salamanca. Sobre el particular, existe en la Biblioteca Nacional una carta inédita en la que, alegando sus propios méritos a la de Prima de Teología, entre otras cosas, decía: "La pretensión es de Prima, que es decir que no hay más que pretender... Joya preciosa es la que pido, así es, yo lo confieso; pero si se ha de dar a servicios hechos, ¿por qué no la he de pedir, habiendo servido a esta escuela desde veintiséis años y graduado de Maestro de veinte y ocho de mi edad, sino el tiempo que diré? Y con ser tantos y tan grandes mis servicios, todos me parecen pocos, según estimo la joya. Póngala V. Md. en manos de quien así la sabe estimar. Bien pudiera haberla pretendido antes, pero como conocía lo que es detúveme... ${ }^{32}$.

Dentro de la Orden, ocupó el cargo de Definidor en 1595, y luego el de Provincial nada menos que en cuatro ocasiones, "como resultado indudablemente de las simpatías que entre los hermanos se había conquistado".

Y como en la vida de estos grandes hombres -grandes por su ciencia y grandes por su humildad- no puede faltar la cruz, esta cuarta elección al pro-

30. La biografía del Ilmo. Antolínez que inserta Vidal en su Historia de Agustinos de Salamanca, y de la que entresaca Vela los datos que trae en su Ensayo (Vol. I, p. 146 y ss.), está sacada en su mayor parte de la oración fúnebre de Fray Basilio Ponce de León.

31. Santiago Vela, G. de, Ensayo, vol. I, l.c., p. 149. 
vincialato fue impugnada "por algunos envidiosos e inobedientes", los cuales se valieron de falsos pretextos y de que en ello se iba en contra de las leyes pontificias, hasta conseguir que lo recluyeran preso en el citado convento de San Felipe el Real ${ }^{33}$.

A pesar de que la elección había sido del todo válida, como consta por un documento existente en la Biblioteca de El Escorial, el P. Antolínez soportó aquella afrenta no sólo con paciencia ejemplar y con resignación más que cristiana, sino que ni siquiera quiso que le defendieran de las inculpaciones de que era objeto, pudiendo perfectamente hacerlo con la seguridad de salir victorioso en el litigio. Prefirió padecer por Cristo aquella contrariedad y mortificación, antes que tocar la honra y buena fama de sus hermanos.

Obtuvo, por fin, permiso para volver a Salamanca, acompañándole en el viaje el insigne Basilio Ponce de León, el cual se admiraba mucho de la tranquilidad y paz de alma del más que probado agustino.

Nos cuenta este otro benemérito religioso que, en llegando a la primera posada de Torrelodones, se puso a continuar con gran serenidad de ánimo la exposición de un salmo que, a imitación de Fray Luis de León, había comenzado en la cárcel. Llegado a Salamanca, fueron varios los colegios que le eligieron por visitador y reformador; mientras que el rey Felipe III mandaba se le consultase en los negocios más graves del reino.

Los biógrafos cuentan que, muerto a mitad de su visita pastoral, "lleváronle en una barca hasta el Padrón, y de aquí a Santiago, donde notaron que el cuerpo, no obstante de no estar embalsamado y haber existido tanto movimiento y excesivos calores -su muerte acaeció el 19 de junio, como queda apuntado arriba-, despedía suave fragancia, y el ostro más parecía de vivo que de difunto. A vista de tales prodigios, el Cabildo convocó a los primeros médicos de la ciudad, los cuales declararon no ser natural el efecto de la incorrupción, con lo que creció la estimación de todos, que ya le tenían por santo" ${ }^{34}$.

32. Antolínez, A., Carta inédita. Biblioteca Nacional de Madrid, Sección de Códices, c. 7314. Cf. VELA, G. de, Ensayo, 1.c., p. 146; a continuación cita las distintas cátedras que había desempeñado, tanto en la Universidad de Valladolid, como en la de Salamanca, a la que dirige la súplica.

33. En la biblioteca de El Escorial existe un impreso en el cual prueba el autor que fue válida del todo la elección recaída en el P. Agustín Antolínez. Lleva el siguiente encabezamiento: "Relación del Capítulo Provincial de la Orden de San Agustín, que se celebró en Madrigal este año de 607, a quatro de mayo. fol. de 8 hs. sin pie de imprenta.

34. Los cronistas Herrera y Vidal, al igual que el citado Basilio Ponce de León, que tuvo la oración fúnebre en las solemnes exequias, relatan una serie de prodigios y hechos milagrosos, atribuidos a la intercesión del siervo de Dios. 
Enterrado y sepultado quedó en la catedral compostelana, junto a la capilla del Santo Apóstol, inmediato a la sepultura de su antecesor el Ilmo. Sr. D. Maximiliano de Austria. Las exequias que se celebraron solemnemente en Salamanca tuvieron por predicador al citado Fray Basilio Ponce de León, que publicó, además del discurso íntegro, una relación de aquellos actos. "Fue sobre todo extremo -diría en aquella ocasión- mansedumbre, paciencia y sufrimiento. Buen testimonio nos ofrece la persecución doméstica. Fue pública, anduvimos en tribunales seglares, todos lo saben, no es mucho que digamos. Fui su compañero en la prisión, y con que he tenido en la vida algunos sucesos bien gloriosos, ninguno lo ha sido tanto en mis ojos, como haber estado preso en compañía de Fray Agustín Antolínez, por haber hecho notificar y ejecutar unas letras de Eugenio IV, concedidas a la Observancia de Castilla, sin embargo de un nombramiento dado con buen celo por el señor Nuncio de España, pero obtenido a fuerza de brazos y con relaciones siniestras. No quiero con esto condenar a los autores de la prisión, que algunos eran de vida al parecer inculpable; sino persuádome a que escogió este medio la Providencia Divina para crisol y purgatorio de alguna imperfección del perseguido... Si hubo para la prisión justa causa, si fue justificada la sentencia, no me toca el examinarlo ahora, sólo digo que el señor Nuncio, que le sentenció, dijo muchas veces en España y Roma que jamás firmó auto contra Fray Agustín Antolínez, sin repugnancia y resistencia interior a lo que firmaba la pluma..."35.

Volviendo a nuestro convento vallisoletano, tenemos que decir que es larga la lista de religiosos que le dieron renombre y fama. Son ellos, entre otros que aparecen más dudosos como profesos del mismo, Fray Antonio de Conderina, hijo de Antonio de Conderina y Antonia de la Vega, vecinos de Bilbao. Ingresó en el monasterio agustiniano, profesando el día 5 de marzo de 1589, en manos del P. Vicario-Prior Fray Antonio de Arce, el cual fue más tarde Provincial de Castilla.

Conderina hizo sus estudios en Salamanca, donde figura en varias listas de estudiantes agustinos que tenían derecho a votar en las provisiones de cátedras. Por el año 1618 lo vemos de conventual en San Felipe el Real de Madrid, donde puso su firma y fechó la aprobación a la obra de Camargo y Salgado, titulada Muerte de Dios por vida del hombre ${ }^{36}$. Fue promovido al obispado de Santa Marta, en Colombia, el 22 de junio de 1630, de donde fue trasladado a la sede de Guamanga en 1640. Se nos dice que, apenas tomó

35. Santiago Vela, G. de, Ensayo..., vol. I, p. 150-151. 
posesión de esta diócesis, "perdió la razón y murió demente el 1648 en el convento de Lima, donde está enterrado" ${ }^{37}$.

Otro de los hijos de este convento agustiniano es el P. Andrés Aguado, nacido en la misma ciudad del Conde Ansúrez, el cual emitió sus votos religiosos el día 10 de junio de 1608, en manos de Fray Miguel Sedeño. Sus padres se llamaron Andrés Aguado y Magdalena de Valdés, vecinos los dos de la villa de Olmedo. Prior y más tarde Definidor de provincia, fue promocionado a la silla episcopal de Ariano, en el reino de Nápoles, el año 1641, en cuya diócesis murió cuatro años más tarde ${ }^{38}$.

Fray Antonio de Castro, aunque nacido en la villa de Almagro, provincia de Ciudad Real, se hizo religinso agustino en el nuestro convento de Valladolid el 24 de octubre de 1603. Los cronistas nos cuentan que emitió los votos en manos de Fray Juan de Castro, que era prior del mencionado monasterio desde el año 1601; el mismo que fue preconizado arzobispo de Santa Fe de Bogotá, en enero de 1608, pero no pasó a gobernar su diócesis por haber sido nombrado predicador real por Felipe III ${ }^{39}$.

Herrera escribe que este buen religioso manchego fue Visitador y Definidor de la Provincia de Castilla, prior de los conventos de Pamplona y San Felipe el Real de Madrid; examinador sinodal del arzobispado de Toledo y últimamente predicador de Felipe IV ${ }^{40}$.

Otra figura a destacar entre los claros varones del convento de Valladolid, natural de la misma ciudad, es Fray Gaspar de Oviedo. Su fecha de nacimiento la colocan en el año 1591 -fecha histórica, en la que murieron el

36. Fray Fernando de Camargo y Salgado, nacido en la villa y corte de Madrid, agustino de San Felipe el Real, fue -según escribe Álvarez y Baena- "maestro en Sagrada Teología y predicador de gran fama en la Corte, en donde era venerado, igualmente por sus letras, que por sus virtudes. Murió a los ochenta años de edad, en su convento de Madrid, a 27 de marzo del año 1652. Toda su vida empleó en el estudio, y así trabajó muchas obras, pues él mismo dice haber escrito 39 libros, grandes, medianos y pequeños". Nicolás Antonio dice, por su parte: "Multa ex propia penu deprompsit historica, poetica, moralia et concionatoria, multa exteriorum opera nostris Castellanis Communicavit".

37. Santiago Vela, G. de, Ensayo de una Biblioteca Iberoamericana, Madrid 1915, vol. II, p. 71.

38. Herrera, T. de, Alphabetum Augustinianum, 1.c., vol. I, p. 48.

39. El Ilmo. Fray Juan de Castro, del que se hacen lenguas los citados Herrera y Vidal, junto con el eminente teólogo y escritor, también conocido de nuestros lectores, Basilio Ponce de León, dejó escritos algunos apuntes acerca de la vida del Beato Alonso de Orozco, que aprovechó luego el P. Juan Márquez para la estupenda biografía que hizo de "El Santo de San Felipe" (Cf. Herrera, T., Historia del Convento de San Agustín de Salamanca, l.c., p. 200).

40. Herrera, T., o.c., p. 179. 
Beato Alonso de Orozco y el Mtro. Fray Luis de León-, siendo su padre Miguel de Oviedo y su madre doña Juana Ruiz.

Se sabe que profesó el día 11 de mayo de 1607, en manos del entonces prior Fray Agustín de Carvajal y más tarde insigne prelado de Panamá ${ }^{41}$. Gregorio de Santiago Vela, que trae otra fecha distinta de profesión ${ }^{42}$, señala, con los cronistas citados, que fue prior del convento de san Agustín de Salamanca en 1638 y presidió, por mandato del P. General, el Capítulo Provincial, celebrado en Madrigal de las Altas Torres en 1644.

Licenciado en Teología por la Universidad de Salamanca en 1631, consiguió el doctorado en la misma facultad el 1632. En el mes de noviembre del mismo año, se presentó a la cátedra de Santo Tomás, consiguiendo la de Escoto en el 1636.

Por motivos internos de la Corporación y que nada tenían que ver con el fiel cumplimiento de sus deberes universitarios, el rey Felipe IV, abusando de sus reales prerrogativas, le privó de la cátedra y le impuso un correctivo tan inadecuado, como injusto.

Así lo reconoció el claustro en pleno, que se dirigió a su Majestad intercediendo en favor el P. Oviedo, a quien en descargo se le concedió la cátedra de Durando, de la que tomó posesión el día 9 de noviembre de 1639.

Tal vez para congraciarse con nuestro agustino, que opositó a la de Prima de Teología, por jubilación del P. Ángel Manrique, de la Orden del

41. El Ilmo. Fray Agustín de Carvajal había nacido en Guadalajara, en cuyo convento tomó el hábito agustiniano. Estudió en la Universidad de Salamanca, donde se graduó en Sagrada Teología, en el año 1586. El cronista de los Agustinos en la Nueva España escribe que fue "Rector y Lector del famoso colegio de San Gabriel de Valladolid y Prior en el convento de San Agustín de esta ciudad, Mtro. en la Provincia de Castilla, y estando ausente de España, fue nombrado Calificador de la Santa Inquisición de Méjico. Pasó a Roma como Definidor general de nuestra Provincia y votó como tal en el Capítulo general año de 1592, en tiempo de la Santidad de Clemente. VIII, que tanto se agradó de su observante vida y loables costumbres, que le envió por Vicario general, Visitador y reformador de la Provincia de Romandiola, y esto cuando con más eficacia trataba su Santidad de restaurar y reformar el estado regular".

Más adelante, dice que, "acabada su asistencia, se volvió a la Provincia de Castilla y la majestad Católica le presentó el año 1605 para el Obispado de Panamá, donde ayudó mucho para la fundación de un convento de la reforma, que establecieron algunos religiosos de la provincia del nuevo Reino; y el año de 1612 fue promovido al Obispado de Guamanga en el Perú, donde murió el año de 1620 , con opinión de muy perfecto Prelado y Obispo de vida ajustada". (Cf. Basalenque, D. de, Historia de la Provincia de San Nicolás de Tolentino de Michoacán, México 1673, lib. I, c. 19, y también MONASTERio, I., en la revista "España y América", vol. XXVII, p. 145.

42. Afirma que profesó el día 11 de mayo de 1611. 
Císter, se le otorgó dicha cátedra por cédula real, tomando posesión de la misma el día 13 de noviembre de 1642.

Promovido a la silla episcopal de Montreal en Sicilia, el P. Bernardino Rodríguez que tenía en propiedad la cátedra de vísperas, el P. Gaspar de Oviedo opositó a ella, ganándola en buena lid y posesionándose de la misma el 17 de octubre de 1648, por medio del P. Miguel García, con poderes que para ello le había dado el agraciado ${ }^{43}$.

Calificador del Santo Oficio, según consta por Herrera, en el Consejo Supremo ${ }^{44}$, murió en pleno ejercicio de su cátedra el día 24 de noviembre del año 1654.

Otro agustino del convento $\mathrm{c}^{\cdots}$ a historia nos ocupa fue el P. Francisco de Villagutierre, el cual era natural de la misma ciudad de Valladolid. Su padre, Juan de Villagutierre, fue oidor del Consejo de Indias, y su madre, doña Isabel de Mercado, pertenecía a una de las familias más ilustres de la ciudad del Conde Ansúrez.

Profesó el año 1603, siendo prior Fray Juan de Castro. Calificador del Santo Oficio, fue nombrado obispo titular de Troya y auxiliar del arzobispado de Toledo, ciudad en la que fue honrado con el cargo de capellán de honor de los reyes de España.

No sería justo cerrar este capítulo de hijos ilustres del convento agustiniano de Valladolid sin citar a Fray Juan de Vera, nacido en nuestra ciudad, hijo del licenciado Francisco de Vera y de doña Leonor Rodríguez, ambos vecinos de la misma y noble ciudad castellana.

Emitió sus votos en este convento el día 6 de mayo de 1570, en manos del prior, a la sazón, P. Gabriel Pinelo ${ }^{45}$. Los cronistas aseguran que "fue uno de los primeros fundadores de la Congregación de los Descalzos Agustinos -así se expresa literalmente Herrera- de España".

El año 1597 fue nombrado Comisario General de los cuatro conventos que por estas fechas habían abrazado la Recolección, siendo más tarde Provincial de la misma.

43. El P. Miguel García era hijo de Andrés García y Ana Santos, vecinos de Tudela de Duero, provincia de Valladolid. Fue calificador del Santo Oficio y Maestro en sagrada Teología. Elegido prior del convento de San Agustín de Salamanca en el Capítulo intermedio de 1654, debió morir sin haber terminado el trienio de su mandato, toda vez que en 1656 fue nombrado opositor a cátedras el P. Alonso de Villarroel por muerte del P. García (Cf. Vrdal, M., Agustinos de Salamanca, Historia del observantísimo convento..., l.c., vol. II, p. 132).

44. Herrera, T. de, Alphabetum Augustinianum, l.c., tom. I, p. 313.

45. El P. Gabriel Pinelo, aunque nacido en la ciudad de Valladolid, era hijo de profesión del convento de Salamanca, donde emitió sus votos el día 14 de enero de 1544 . Llegó a ser maestro en sagrada Teología y gozó de gran crédito y estimación entre los sabios y los personajes de la corte, y muy en especial del rey Felipe II, el cual solicitó en varias ocasiones su parecer 


\section{FRAY LUIS DE LEÓN EN EL CONVENTO Y CIUDAD DE VALLADOLID}

Fray Luis de León, cuyo centenario de su muerte coincide con el del Beato Alonso de Orozco, "príncipe de la lírica hispana" y "síntesis del Renacimiento español", nacido en la villa conquense de Belmonte -o "Bellomonte", en la "Mancha de Montearagón", como dice él mismo-, pasó por la ciudad de Valladolid y residió en ella en los primeros días de su infancia.

Belmonte, descrita por Pedro de Lorenzo como una villa clara, un bello Monte, pasado Mota del Cuervo y siguiendo el Pedernoso, fiel a sus raíces, en su suelo de pastizales y vuelo de carrascas entre carreteras de pinos ralos, y que se recuesta a la sombra de las seis torres del castillo, sobre otra cima enfrente la colegiata, caserones de escudos ostentosos, cerrado por la muralla que le atenaza a media ladera, había sido la patria chica de los hermanos Juan y Alfonso de Valdés, célebres humanistas, amigos y seguidores de Erasmo, el primero de ellos secretario y defensor del emperador Carlos V, con sus famosos Diálogos de las cosas ocurridas en Roma, y Diálogos de Mercurio y Carón, en los que, imitando los de Luciano de Samosata y del propio maestro Erasmo, sale en defensa de la política del Emperador, con el deseo de difundir la nueva espiritualidad que propugnaba el de Rotterdam; y el segundo, Juan de Valdés, de sobra conocido por su libro Diálogo de la lengua, en el que con natural y elegante estilo, con sencillez y "sin afectación alguna", defenderá igualmente el empleo de la lengua entre los mismos humanistas que tenían a gala el cultivo de un latín ciceroniano.

En Belmonte, de Cuenca, nació también el Condestable de Castilla, Miguel Lucas de Iranzo, amigo y protegido de Enrique IV, que fue quien le otorgó el honroso título, convirtiéndose luego en el favorito del monarca; si bien, más tarde, debido a la enemistad con el marqués de Villena, cayó en desgracia, siendo encarcelado. Recuperada la confianza real, fue nombrado alcaide de Jaén. Partidario ardiente de Enrique IV durante la guerra civil castellana, resistió varios ataques en dicha ciudad, hasta que fue asesinado mientras asistía a misa, seguramente que a causa de su protección de los conversos jiennenses. El nombre de Miguel Lucas de Iranzo va asociado al inte-

para asuntos graves de Estado. El mismo monarca le nombró su predicador y lo fue también de la emperatriz doña María, su hermana. Fue Definidor de Provincia en 1569, presidiendo por este título el Capítulo de 1572, celebrado el 19 de julio en Valladolid. Fue también prior del famoso convento de San Felipe el Real de Madrid. Su fallecimiento debió ocurrir por los años de 1595 . 
resante libro titulado Relación de los fechos del Condestable Miguel Lucas de Iranzo ${ }^{46}$.

De Belmonte era también el agustino Luis de Montoya, profeso del convento de Salamanca, maestro de novicios del beato Alonso de Orozco, amigo personal del desafortunado don Sebastián, rey de Portugal, reformador de la Orden en este país vecino y hermano, más que nunca ahora unido a España, tras la muerte o desaparición de aquel monarca en aguas de Alcazarquivir y cuando Felipe II consiguió la verdadera "Unidad Hispánica" en $1581^{47}$.

La fecha de nacimiento del Mtro. León, discutida entre los diversos biógrafos, párece que fue el 23 de agosto del año 1527, el mismo año en que, precisamente aquí, en la ciudad de Valladolid, naciera Felipe II, en el antiguo palacio de don Bernardino Pimentel y doña Constanza de Bazán Osorio, su esposa, el día 21 de mayo.

A los cinco o seis años, por causas que aún no han sido puestas en claro, salió de Belmonte con su padre, Lope de León, abogado famoso, y tras una breve estancia en Madrid, vino a vivir a Valladolid. Ya por entonces -se nos dice-, "sabía leer y cantar", notable precocidad y preludio de su vocación

46. Esta obra fue debida acaso a un pariente suyo o, según otras atribuciones no comprobadas, a su secretario Luis de Castillo, a Juan de Olid, o tal vez a Pedro de Esquivias, autor de Repertorio de príncipes.

La Relación es una importante biografía particular que, además, trata de todo lo acaecido en los dominios del condestable desde el 1458 a 1471 . Tiene un gran interés por la descripción que hace de las costumbres de la época, principalmente ceremonias, festejos, indumentaria y mobiliario.

47. El venerable Fray Luis de Montoya era natural de Belmonte, de la provincia de Cuenca, la patria de Fray Luis de León. En 1514, cuando contaba los dieciséis años de su edad, tomó el hábito de San Agustín en el convento salmantino, haciendo su profesión el día 27 de abril del año siguiente. Acabados sus estudios, fue enseguida nombrado maestro de novicios, teniendo como súbdito aventajado al beato Alonso de Orozco.

Al fundarse el convento agustiniano de Medina del Campo, en 1525, pasó a esta población de superior de los religiosos que se había traído consigo desde Salamanca, gobernando aquella comunidad por espacio de nueve años. En el año 1535 fue enviado por el Rmo. P. General al reino de Portugal en calidad de Visitador y Reformador de los agustinos. En Portugal fue maestro de novicios y prior del histórico convento de Lisboa, donde dejó como recuerdo indeleble de su celo y actividad religiosa la hermosa iglesia, comenzada en 9 de marzo de 1556 y terminada el 14 de agosto de 1564.

Bajo el mecenazgo del rey Juan III, fundó el colegio de Coimbra, que llegó a adquirir mucha celebridad, siendo uno de los principales centros de estudios en la Provincia de Portugal. Asistió al Capítulo general, celebrado en Bolonia el 1551. Nombrado confesor del rey don Sebastián, de quien había sido su preceptor anteriormente, declinó este honroso cargo, al igual que renunció a la silla episcopal de Viseo. Después de más de treinta años de trabajos en la nación hermana, encaminados a la restauración de aquella Provincia, murió en la paz del Señor en el convento lisboeta el 7 de septiembre de 1569 , dejando el olor de sus virtudes, la memoria de sus hechos en vida y la de varios prodigios obrados con sus reliquias después de su muerte. 
artística, que tantas glorias y alabanzas le acarrearía cuando, ya maduro, escribiera la oda sinfónica al maestro Salinas, y que comienza:

"El aire se serena

y viste de hermosura y luz no usada,

Salinas, cuando suena

la música extremada

por vuestra sabia mano gobernada".

Más tarde, a los catorce años de edad, cuando el autor de sus días fue nombrado Oídor de la Cancillería de Granada ${ }^{48}$, marchó a Salamanca, cursando aquí los estudios universitarios de cánones, en que tanto sobresalía su padre y cuyo catedrático de prima lo era, en aquella sazón, su tío Francisco de León.

Sintiendo en su pecho el deseo de servir a la Iglesia -según declara él mismo-, abandonó el brillante porvenir que podía esperarse de su clara inteligencia y de la influencia de su familia, y se refugió en el convento de San Agustín de Salamanca, plantel de sabios y santos, y que entonces empezaba a subir por las cumbres de la nombradía y de la fama, para llegar a su máximo esplendor precisamente con el Maestro León, el cual profesó en él el día 29 de enero de 1544, cuando aún no había cumplido los dieciséis de su edad.

Justamente en el año del noviciado de Fray Luis de León, 1543, se celebraron en Salamanca las bodas del príncipe don Felipe con su prima, la infanta María de Portugal; las bodas del heredero Carlos V, al que con seguridad había visto más de una vez el hijo de Lope de León en Valladolid, ya que contaba entre sus parientes con cortesanos que frecuentaban el palacio real.

Se cuenta que don Felipe, una vez que fueron terminados los solemnes festejos y antes de salir de la ciudad charra, el 19 de noviembre, fue a escuchar una clase de labios de Fray Domingo de Soto, que era ya una de las grandes lumbreras de la Universidad. El anciano Vitoria, del que tanto se

48. Lope de León, oidor de Granada, padre de Fray Luis de León, ejerció este cargo desde el año 1541. Según una interesante nota que encontramos en el libro de A.F.G. Bell, sobre el Mtro. León, la Cancillería de Granada fue establecida el año 1506 y correspondía a la de Valladolid para el Norte. Al parecer, era costumbre nombrar castellanos para las Cancillerías del Sur y gente del Sur para la de Valladolid, según nos cuenta Cabrera en su Historia de Felipe II. El cargo de oidor tenía importancia dentro del reino; como se puede comprobar leyendo, incluso, las páginas del Quijote, donde Cervantes lo elogia, en el capítulo XLII de la primera parte. 
esperó en el por demás diferido Concilio de Trento, estaba ya en el ocaso de su vida laboriosa, y Melchor Cano aún no había salido a escena ${ }^{49}$.

$\mathrm{El}$ joven agustino, una vez profeso, continuó los estudios y “con su raro ingenio y mucha aplicación, salió tan consumado en muchas facultades -según escribe Vidal-, que con razón fue tenido por milagro de sus tiempos". Por eso, no es extraño que conociera la admiración y también la envidia. Él era un hombre activo, emotivo, primario. De bruscas reacciones, de emociones intensas. No podía estar ocioso, pasar el día mano sobre mano. En su vida gravitan por igual armonía y desequilibrio; borrasca y deseo de paz no alcanzada, pero siempre presentida; vislumbre de la gloria y deleite anticipado; deseos de vida retirad? $\mathrm{y}$, por otra parte, vida metida en mil tareas e inquietudes. Él sintetizó tendencias dispares, lo mismo que supo armonizar, bajo una severa disciplina, su personalidad. Él era reflexivo y, también, sistemáticamente inhibido y melancólico. Riguroso y rebelde. Mezcla de luz y de sombras. Receloso y humilde. Todo un carácter; pero un carácter difícil, inclinado a estallar de enfado. Místico y moralista. Propicio al resentimiento. Conservador y, al mismo tiempo, novedoso y restaurador...

Quizá un poco por todo esto, el Mtro. León conoció la cárcel inquisitorial de Valladolid, donde permaneció cinco años; hasta que, reconocida su inocencia, volvió a sus aulas salmanticenses y a su cátedra de Escritura. Bien pudo escribir entonces, en el húmedo muro de piedra de Campaspero la famosa décima:

"Aquí la envidia y mentira
me tuvieron encerrado.
Dichoso el humilde estado
del sabio que se retira
de aqueste mundo malvado,
y con pobre mesa y casa,
en el campo deleitoso,
con solo Dios se compasa,
y a solas su vida pasa
ni enviado ni envidioso".

En la cárcel, "porque no sé lo que Dios será servido ordenar de mí -escribió-, ni cuándo ni cómo querrá su Majestad llamarme”, para descanso de su conciencia, hizo una protesta de fe, por la que manifiesta que "vivo y muero, viviré y moriré en la fe y creencia que tiene y cree la Santa Madre Iglesia Católica, Apostólica, Romana, a cuya santa doctrina, como doctrina

49. Bell, A.F.G, Luis de León. Un estudio del Renacimiento Español, Ed. Araluce, Barcelona 1923 , p. 110. 
verdadera y enseñada por el Espíritu Santo, sujeto todo mi seso y entendimiento, con ánimo cierto y deseoso de morir por la confesión y defensión de ella todas las veces que se me ofreciere ocasión".

Pero Fray Luis de León “jamás deseó tanto la vida” como en los días de su prisión. Y así, ironiza cuando pide que le den un cuchillo, pues anda mal de la dentadura, y se lo entregan recortado, "para, de este modo, prevenir un posible suicidio". En la cárcel de Valladolid sintió consuelos -“Al gran Consuelo, subido he por la pena", dirá-, que jamás había sentido en momentos más felices de su vida.

Ya es otra la vida del Maestro salmantino. El día 30 de diciembre de 1576 entraba triunfante en Salamanca al son de trompetas y atabales, acompañado de religiosos de la Orden, estudiantes de la Universidad y caballeros de la ciudad charra, maestros y doctores y de numerosa muchedumbre.

Cuando, al día siguiente, se presentó en su antigua aula y rogado que dijera algo, lo que fuese servido, parece que no dijo nada. Renunció a su cátedra en quien entonces la tenía y acaso -porque se ha discutido que sea genuina la frase de Fray Luis- aquello de "dicebamus externa die"...

Fray Luis estuvo en más ocasiones en nuestra ciudad. Una de ellas, a su paso camino de Granada, en 1562, para asistir a la muerte de su padre, y dejando en el Tribunal que años adelante le habría de juzgar "unos papeles referentes a la Inquisición".

Más tarde, en 1580, se sabe que pasó los primeros meses de este año, en el que publicó su primera obra, In Cantica Canticorum et In Psalmum XXVI ${ }^{50}$. Un año más tarde, recibía la gran satisfacción de que aquí, en Valladolid, el mismo Consejo Inquisitorial que le había condenado a la cárcel, le devolvía la cátedra de Biblia, que conservó y explicó hasta la hora de su muerte.

Una muerte que le llegó, serena, nueve días después de haber sido elegido prior Provincial de Castilla en el Capítulo celebrado en Madrigal de las altas Torres. Era el día 23 de agosto de 1591. Alguien ha podido escribir que murió de pena, al saber que el rey Felipe II había aconsejado a los agustinos que no le votasen para aquel cargo.

Qué fundamento había para ello, no lo sabemos con certeza. Lo que sí es cierto es que los encuentros entre el rey y el Mtro. León habían sido tensos y desafiantes. De modo especial, cuando en el asunto de las monjas carmelitas, convoca por dos veces el Capítulo de la Orden y por dos veces se lo prohíbe el monarca.

50. Todos estos datos históricos han sido tomados de la revista "Religión y Cultura", Año I, t. II, Abril-Junio de 1928, p. 335 y s. 
Como también es cierto que, solapadamente, el agustino había ironizado sobre la construcción de El Escorial, y ladinamente en alguna ocasión había llamado a Felipe II "Tirano", como se lo llamaba a sus superiores; a algunos de ellos, por lo menos. Por lo que el cardenal don Pedro de Quiroga, inquisidor mayor y amigo personal de los agustinos, hubo de llamarle la atención, en 1584, al tiempo que le impedía un segundo proceso contra el autor de Los Nombres de Cristo y de La Perfecta Casada.

Enterrado fue en el convento de San Agustín de Salamanca, delante del altar de Nuestra Señora de Pópulo. Y, exhumados sus restos el 16 de marzo de 1856, fueron trasladados a la capilla de San Jerónimo, en la Universidad, de la que fue genuina y acaso la más preciada lumbrera.

\section{Santo Tomás de Villanueva en el convento de San Agustín de VALLADOLID}

Padre de la Iglesia española y de la Orden Agustiniana, nacido en 1488 en Fuenllana, pueblo entonces de la diócesis de Toledo, a media legua de Villanueva de los Infantes (Ciudad Real), que nos recuerda a don Francisco de Quevedo y Villegas ${ }^{51}$; graduado en filosofía y teología por la Universidad de Alcalá, donde leyó con provecho cursos de artes y de teología, teniendo por discípulos, entre otros, a los insignes Hernando de Encina y Domingo de Soto, invitado por la Universidad de Salamanca a que explicara en ella la cátedra de filosofía natural, renunciando a una carrera brillante, tomó el hábito agustiniano en el convento de la misma ciudad del Tormes en 1516, a los treinta años de su edad.

Dos veces prior de este convento, la primera de ellas cuando sólo llevaba dos años de profeso, es decir, en 1518, en la segunda ocasión tuvo la dicha de dar la profesión al beato Alonso de Orozco, acaso su discípulo más querido y aventajado en ciencia y virtud. Este mismo año se ordenó de sacerdote y dijo su primera misa en el convento salmantino.

Celebrado Capítulo Provincial en 1519, fue nombrado prior del mismo y famoso monasterio; otorgándole este mismo honor el año 1522. Prior Provincial de la nueva Provincia de Andalucía, en 1527, una vez que ésta se reintegró nuevamente a la de Castilla, fue superior Mayor de esta Provincia en 1534. Dos veces prior del convento de Burgos -en los trienios de 1534 y

51. Don Francisco de Quevedo y Villegas, nacido en Madrid el año 1580, fue a morir en la ciudad de Villanueva de los Infantes. En sus años de infancia, llegó a conocer y tratar personalmente al Beatro Alonso de Orozco, al que visitaba, por encargo de sus padres, en el convento de San Felipe el Real. Devoto de Santo Tomás de Villanueva, escribió una Vida admirable sobre el santo limosnero de los pobres y arzobispo dé Valencia el año 1620. 
1537-, lo sería, igualmente, del convento de San Agustín de Valladolid en 1541.

Éste fue el último cargo que recibió por parte de la Orden, antes de que el Emperador le instara a que aceptase la mitra del arzobispado de Valencia -anteriormente había rechazado la de Granada-, por cédula que le envió el año 1544 a la ciudad de Valladolid, donde residía el príncipe don Felipe y el santo agustino, terminando su oficio de prior. Los biógrafos cuentan que fue tanta la resistencia que encontró el heredero de la corona imperial, que hubo de reclamar la ayuda del Superior Provincial, a la sazón, Fray Francisco de Nieva ${ }^{52}$, el cual le mandó en virtud de santa obediencia que aceptara aquel nombramiento "antes de pasadas veinte horas". Dos días más tarde, daba su consentimiento.

El día 10 de octubre del mismo año 1544 fue preconizado por el papa Paulo III. Pocos días después, todavía en nuestra ciudad, recibió las bulas de Roma, siendo consagrado por el cardenal arzobispo de Toledo, Ilmo. Juan de Tavera ${ }^{53}$.

El día 22 de diciembre llegaba a Valencia, hospedándose en el convento agustiniano de Nuestra Señora del Socorro, que estaba a las afueras de la ciudad. Su entrada en la catedral del Turia la haría ya en los primeros días del año 1545. Diez años gobernó admirable y santamente su diócesis, recorriendo y visitando, uno a uno, todos los pueblos de la misma -cosa que entonces no solían hacer los prelados-, ejerciendo a manos llenas la caridad para con los pobres - no en vano ha sido apellidado "el padre de los pobres"-, entregando todo cuanto tenía a los necesitados, incluso su lecho, una vez que muriera, a su fiel servidor Benito, el día 8 de septiembre, festivi-

52. De Fray Francisco de Nieva se hacen lenguas los cronistas del convento de San Agustín de Salamanca. Hijo del convento de Salamanca, fue por primera vez prior del mismo el año 1525 , por nombramiento del Capítulo provincial celebrado en Valladolid, estando presentes los dos visitadores y reformadores, Fray Juan Gallego y Fray Tomás de Villanueva.

Por segunda vez fue superior del mismo y celebrado convento en el año 1534, y también por nombramiento oficial en el Capítulo provincial habido en la ciudad de Burgos. En este mismo Capítulo salió electo nuevamente Provincial Santo Tomás de Villanueva, el cual habría de encontrar en el P. Nieva el más firme apoyo y colaborador para el envío de misioneros a la Nueva España.

53. El Ilmo. Juan de Tavera había nacido en la histórica villa zamorana de Toro (1472), para morir en la ciudad de Toledo el año 1545. En el año 1506 fue nombrado consejero de la Inquisición, canónigo de Sevilla, provisor y vicario de esta sede episcopal. Nombrado obispo de Ciudad Rodrigo el año 1514, lo fue al poco tiempo de Osma y, posteriormente, arzobispo de Santiago. El mismo año en que tomó posesión de esta sede (1525), el emperador Carlos V le designó presidente del Consejo de Castilla y de la Chancillería de Valladolid. Fue gobernador de la corona de Castilla durante el viaje de Carlos V a Italia. En 1531 fue elevado a la dignidad cardenalicia y, después, a la sede metropolitana de Toledo. 
dad de la Natividad de Nuestra Señora, de la que tan sabrosas páginas escribiera y hermosos sermones predicara, entregó su alma al Creador. Al día siguiente -nueve de septiembre de 1545- fue enterrado en la iglesia del citado convento agustiniano de Ntra. Sra. del Socorro. El que había dejado una brillante carrera y una rica hacienda, heredada de sus padres, deseó siempre que sus restos fueran a parar a la oscuridad y pobreza de un sencillo sepulcro conventual.

Don Francisco de Quevedo, refiriéndose al santo limosnero de los pobres, en la espléndida biografía que escribió sobre el mismo, dice que "tenía memoria de todos los pobres vergonzantes, y en papelillos les daba el dinero, cuando salía de casa, y cuando pasaba a decir misa. A otras personas principales y de calidad, que él sabía que tenían necesidad y vergüenza de pedir limosna, por excusarlos algún sentimiento, los socorría engañándolos. Enviaba a uno cincuenta ducados, a otro ciento, y doscientos, y más conforme era la necesidad, con religiosos, diciendo que una persona que les tenía a cargo alguna hacienda les restituía aquella parte, y que, poco a poco, iría satisfaciendo como mejor pudiese y se desvelaba en ocultar su misericordia".

El año de 1550 -sigue diciendo el biógrafo del santo arzobispo- el célebre corsario turco Dragut ${ }^{54}$ saqueó la ciudad valenciana de Cullera, "y en sabiéndolo el santo -escribe literalmente- envió sus limosneros a que rescatasen los cautivos y consolasen a la ciudad, se comprasen bueyes y mulas a los labradores; y todo se hizo con su limosna: cosa admirable y de efecto milagroso" 55 .

Concretándonos a su estancia en la ciudad de Valladolid, el mismo Quevedo y, por supuesto, los cronistas de la Orden, declaran que el año de 1541 se celebró capítulo Provincial en Toledo. Era entonces Superior Mayor de la Orden el Rdmo. P. Jerónimo Seripando ${ }^{56}$, el cual conociendo la valía de

54. Dragut, en turco "Turgud", fue un corsario, nacido en Anatolia, y muerto en Malta el año 1565. Comenzó a hacerse famoso en 1533 entre los corsarios que atacaban a los navíos venecianos en el mar Egeo. Los genoveses le capturaron en 1540, pero fue rescatado por Jayr al-Din Barbarroja, participando luego en las expediciones de éste, e instalando más tarde su cuartel general en Al-Mahdiyya, conquistada por él a los españoles. Al recuperarla de nuevo por éstos en 1550, se instaló en Yerba, donde fue bloqueado en 1551 por Andrea Doria, pero logró escapar mediante una audaz estratagema. Sirvió más tarde al imperio otomano. Pereció el año citado de 1565 durante el asedio de Malta.

55. QUEVEDO Y VILlegas, F. de, Vida ejemplar y religiosa muerte del bienaventurado Sto. Thomás de Villanueva, Arzobispo de Valencia. En Vidal, M., Agustinos de Salamanca. Imp. Eugenio García de Honorato y S. Miguel, Salamanca 1751, p. 221.

56. El Rmo. P. Jerónimo Seripando, figura estelar de la Orden de San Agustín y de la Iglesia Católica, teólogo de Trento, ingresó en los agustinos de Nápoles el año 1507. En Roma, se encontró en 1510 con Lutero. Ordenado de sacerdote en 1513, fue designado, años más tarde, en 1538, prior general. Desde su alta magistratura, hubo de hacer frente a la Reforma, que atra- 
nuestro agustino, quiso hacerle provincial, y con este deseo y el de ver tan santo religioso y tan docto, le mandó llamar. Fray Tomás de Villanueva, "sospechando o entendiendo que le quería poner en esta dignidad, se excusó y entretuvo el viaje de suerte que llegó cuando era fuerza estar electo Provincial. Y consolóse con verle, recibiéndole con aquellas palabras de la Virgen a su hijo: "Filii, quid fecisti nobis sic. Ecce pater tuus et ego dolentes querebamus te". El afecto y reverencia con que este Rmo. Cardenal le tratase, se conoce de las cartas que le escribió, certificando no venía a España con otro deseo mayor que el de ver tan santo varón" ${ }^{57}$.

Pero este modelo de religiosos que, según el mismo Quevedo, "después de profeso, fue más novicio que antes en la obediencia; y después de superior, se preció más de súbdito", no pudo por menos de seguir al mando de las comunidades que le encomendaba la misma obediencia. $\mathrm{Y}$ así, en este mismo Capítulo de Toledo tuvo que aceptar el cargo de prior del convento de San Agustín de Valladolid. Fray Tomás de Villanueva, si había en su comunidad alguna disensión, trabajaba lo indecible por componerla; de tal manera que "era la paz en todas partes donde se hallaba. Era el consuelo para todos los que tenían necesidad de él, y el maestro de los que deseaban aprovecharse".

Además de esto, en las ciudades de Burgos, Valladolid y Salamanca, mientras estuvo de superior en sus respectivos monasterios, "aprovechó con doctrina, admiró con sus milagros y edificó con su vida".

Era tan grande su autoridad en todas partes, que su ruego acabó negocios de venganza, que se negaron a los hijos y a los padres. Cuando pasaba por las calles, se arrodillaban todos, mortificando grandemente su verdadera humildad.

Precisamente en los días en que fue superior del convento vallisoletano, sucedió el célebre caso denominado de los Caballeros "lasios" ${ }^{58}$, los cuales habían sido condenados por el emperador Carlos $\mathrm{V}$ a ser degollados por un gravísimo delito. Los Grandes del reino le pidieron perdón y suplicaron todos, reunidos ante Su majestad, que les levantara la condena de muerte.

jo a muchos agustinos de Alemania. Legado del papa en el Concilio de Trento, cardenal de la Iglesia, destacó por su sabiduría y prudencia al tiempo de dirigir los debates conciliares sobre el arduo problema teológico de la justificación. Presidente del Concilio en 1561, participó activa y sabiamente en la Contrarreforma; hasta el punto de que, en su deseo de conciliación, hubiera querido, incluso, que los luteranos acudieran al Concilio, para cooperar también ellos en la reforma de la Iglesia. (Sobre el P. Seripando se han escrito admirables biografías. Recomendamos la ejemplar y modelo del historiador Hubert Jedin, y el magnífico estudio que le dedicó el agustino P. David Gutiérrez).

57. QueVEDo Y Villegas, F. de, o.c., p. 217.

58. Este suceso lo cuenta con detalle el mismo Quevedo en la biografía citada, p. 216. 
Al ver que nada conseguían, se fueron al príncipe heredero don Felipe, el cual, "se arrodilló ante su padre y se lo suplicó", también, sin conseguir la deseada indulgencia.

Entonces acudieron a Fray Tomás de Villanueva, el cual entró a la presencia de Carlos $\mathrm{V}$ y humildemente intercedió por los condenados a muerte. El emperador lo mandó levantar y le dijo: -Hágase luego lo que pedís. A vos, Fray Tomás, no os puedo yo negar nada, conociendo que sois enviado del cielo por ministro de la caridad y misericordia.

El historiador Tomás de Herrera dice que "el cristianísimo Emperador y rey católico de las Españas, Carlos V y su augusta esposa ${ }^{59}$ deseando oirle predicar, le llamaron no pocas cuaresmas, y en otros muchos días festivos, y declararon aquellos cristianísimos príncipes, con significación clara, que con sus sermones sentían en su alma gran consuelo".

Y añade luego, muy ingenioso: "Lo que a mí me parece como milagroso es que acudían a porfía a sus sermones, picados del espíritu, como de tábano, de todo orden de hombres y de todo estado y condición de gentes. Dejo ahora el vulgo innumerable de la muchedumbre mezclada que, como sin saber de sí, se encendía en piedad; también dejo los próceres y los grandes y cualesquiera majestades y varones señalados con el Orden de Caballería militar; y que todos, arrebatados con increíble ardor, se conmovían a buscarle; pero -esto es lo que hace causarme mayor admiración- arrebataba tras sí de donde quiera a los hombres letrados, a los grandes predicadores, a los frailes de casi todas las religiones $\mathrm{y}$, finalmente, a los varones llenos de letras y erudición, con ansia y deseo de oirle, como olvidados de sí; cosa de verdad dignísima de grande admiración, por satisfacer tan bastamente a tan diversos ingenios de hombres con una misma oración. Éstas son fuerzas divinas de la verdad pura y virtud sencilla" ${ }^{60}$.

En el mismo sentido se expresa Quevedo cuando escribe que "fue predicador de la Majestad del Emperador, a quien oía con tanto gusto, que le tenía ordenado avisase dónde predicaba, porque quería oirle siempre que pudiese". A continuación narra una anécdota encantadora. "Avisó que predicaba un día en su casa, en Valladolid. Y el César, codicioso de oír al santo, fue muy temprano y a esperar la hora del sermón. Se entró con los Grandes en el claustro diciendo al portero:

-Decidle a Fray Tomás que estoy aquí, que baje.

Fue el portero y respondió, con él, el santo a la Majestad Cesárea:

59. La emperatriz doña Isabel de Portugal, madre de Felipe II. 313-14.

60. Herrera, T. de, Historia del convento de San Agustín de Salamanca, Madrid 1652, p. 
-Que estaba estudiando, que si había de predicar, no podía bajar; y que si bajaba, no predicaría.

Pareció a los que acompañaban al Emperador despego y descortesía, y diéronlo así a entender, obligando a que su Majestad dijese:

-A mí me ha edificado lo que a vosotros os ha escandalizado; y quisiera yo mucho que todos los predicadores y religiosos fueran tan desasidos de la vanidad y tan despegados de la grandeza como Fray Tomás" ${ }^{61}$.

Se comprende perfectamente el talante de Carlos $V$ y cómo pensaba de nuestro agustino, pues su amistad venía de tiempo atrás, y de cuando, deseando hacerle arzobispo de Granada -ciudad muy querida del Emperador-, se negó a aceptar aquella mitra con estas tan humildes, como sencillas palabras:

-Cayendo y levantando, voy con el poco peso de mi Religión y este hábito; y veo vacilar mis fuerzas con solo el cuidado que de mí tengo en esta correa. ¿Cómo queréis que me atreva a repartir lo que en sí es tan poco, y apenas basta para mí, con tantos?".

Uno de sus primeros biógrafos, P. Miguel Salón ${ }^{62}$, escribe que, a la hora de hacer el proceso de beatificación y canonización de Fray Tomás de Villanueva, muchas y muy graves personas de Castilla, particularmente de Valladolid y de Burgos, testifican "que era tan grande la opinión de su santidad, justamente debida a su santa vida, y religiosísimas costumbres, que así los frailes, como los seglares, donde quiera que estuvo, le reverenciaban como a

61. Quevedo y Villegas, F. de, o.c., p. 216.

62. El P. Miguel Bartolomé Salón era natural de Valencia. Después de estudiar Artes, ingresó en el convento de Ntra. Sra. del Socorro de su ciudad, haciendo su profesión el 20 de junio de 1588, en manos del entonces prior Pedro Ramos.

Los cronistas del convento citado nos dicen que estudió con mucho lucimiento filosofía y teología y después cánones y leyes. En 1563, siendo ya Lector, el P. General de la Orden le concedió el título de Bachiller. Se graduó después de Maestro en la Universidad valenciana, alcanzando el grado de Doctor en teología y en ambos derechos el día 10 de octubre de 1588.

Profesor en la universidad valenciana, ganó la cátedra de Santo Tomás; cátedra que regentó durante cuarenta años. Se nos dice también que era pequeño de estatura y de complexión enfermiza, pero de espíritu tan agigantado como lo manifiestan sus obras magistrales y los muchos cargos que ocupó dentro y fuera de la Orden. El rey Felipe III le tenía en un alto grado de estima. Afiliado su convento a la Provincia de Aragón (había pertenecido a la de Cerdeña), el P. Salón quedó afiliado a la misma, en la que ocupó diversos cargos, asistiendo el Capítulo General con título de Definidor y en representación de la Provincia, celebrado en Roma el año 1575.

Gran amigo del Bto. Juan de Ribera, patriarca y arzobispo de Valencia, fue su consultor en problemas graves de la diócesis, como en el delicado caso de la expulsión de los moriscos. La Universidad citada tenía tal confianza en su catedrático, que le confió la redacción de las Constituciones. Falleció siendo prior del convento del Socorro el día 25 de enero del año 1621. 
santo. $\mathrm{Y}$ en las calles por donde pasaba, salían de las casas a besarle las manos, y la ropa, y las señoras principales salían a las ventanas y desde allí, arrodilladas, le pedían la bendición" ${ }^{63}$.

Más adelante, añade: "Bien público fue también en toda España lo mucho que le estimó y amó el Emperador Carlos Quinto, y no menos su hijo Felipe II, que está en el cielo y vióse bien en lo que se sigue...".

Lo que se sigue es el suceso que ya nos ha contado arriba don Francisco de Quevedo: el triste acontecimiento ocurrido en palacio, mientras residía la Corte en Valladolid, con unos caballeros, "criados del Emperador", a los que, todo ofendido el César mandólos buscar con diligencia y, una vez encontrados, sentenció para ellos y sin remisión alguna la pena de muerte.

Salón añade a lo narrado por don Francisco de Quevedo que, al salir de la cámara real, Fray Tomás fue rodeado por los caballeros que esperaban la condena de muerte, preguntándole ansiosos cómo había ido la entrevista con el Emperador. A lo que el santo prior del convento de San Agustín respondió:

-Con el favor de Dios, todo irá bien.

Pero todos entendieron que estaban perdonados e inmediatamente entraron a besar la mano del César por aquella merced. Fue entonces cuando Carlos V, para que no se maravillase nadie de que hubiese concedido a Fray Tomás la gracia que a todos cuantos estaban presentes había negado anteriormente, les dijo:

-No os espantéis haya perdonado a esos caballeros la vida por lo que me ha rogado el prior de San Agustín; porque ese religioso no ruega, sino que manda y mueve los corazones ${ }^{64}$.

\section{El BeAto alonso de OROZCo en VAlladolid}

Fray Alonso de Orozco, "hombre de Dios y hombre entre los hombres", "hombre docto y santo", "varón insigne en ciencia y virtud", "hombre de ayer y de hoy", florón de la Universidad de Salamanca, religioso agustino y sacerdote ejemplar de la Iglesia, consejero y amigo íntimo de Felipe II, amigo también y limosnero de los pobres, feliz nacido que abarca la edad de oro española, oriundo de un señorío de Vizcaya, había nacido en Oropesa,

63. SAlón, M., Vida de Santo Tomás de Villanueva. Imp. Eugenio García de Honorato, Salamanca 1737. Esta biografía del P. Salón viene "Añadida y nuevamente reimpresa por el P. Manuel Vidal" en el año citado de 1737.

64. Ibid., p. 85 . 
entonces perteneciente a la diócesis de Toledo, ciudad ubicada hoy en la provincia de lo que fuera capital del reino visigodo.

"Mi nacimiento fue en Oropesa -escribirá Fray Alonso en el libro de sus Confesiones; reinando la muy católica reina doña Isabel, de gloriosa memoria" ${ }^{65}$. Efectivamente, el día 17 de octubre del año jubilar de 1500 , nacía el hijo ilustre de Hernando de Orozco y de doña María de Mena. Ocho años atrás, se había consumado la unidad nacional por la rendición de Granada, y se había descubierto el Nuevo Mundo, el mayor acontecimiento que registra la Historia, después del nacimiento de Cristo.

Hernando de Rojas, uno de los primeros biógrafos del P. Orozco, que le conoció en vida y le tuvo de súbdito y penitente en el colegio de Doña María de Aragón, fundado por nuestro agustino, actualmente convertido en el Senado Español, dice que, después de residir en Talavera de la Reina y en Toledo, con la idea de que un día pudiera ser sacerdote, los padres le enviaron a estudiar a Salamanca, donde ya le había precedido un hermano suyo, por nombre Francisco ${ }^{66}$.

Salamanca y su Universidad -la Sorbona de España- subía entonces presurosa, a impulsos de su ingenio y entre las caricias de la fortuna, a la más alta cumbre de la sabiduría. Los distintos papas la habían enriquecido con privilegios y dotado, como a hija predilecta, con pingües rentas. Por su parte, los reyes de España, cubriéndola con su manto real, la estimaban como el principal ornamento de su corona y eximían a sus maestros de gabelas y de otros cargos comunes.

Pues bien, entre los nobles e hidalgos mancebos que de todos puntos de la Península acudían a beber en sus aulas de la inagotable fuente de sabiduría, se distinguían por su religiosidad y compostura dos jóvenes llegados desde la ciudad de Toledo. Se llamaban Francisco de Orozco, que era el mayor y Alonso de Orozco, nuestro personaje.

Cuando más entregados estaban a los estudios de Leyes, se le ocurrió a Francisco hacerse fraile de San Agustín. Enterado Alonso, "le rogó muchas veces -escribe Hernando de Rojas- que negociase la frailía para entrambos" ${ }^{67}$.

Y como el hermano mayor le dijo:

65. Orozco, A. de, Confesiones. Ed. Amigos del País, Manila 1882, p. 1.

66. RojAs, H. de, Relación de la vida del Ven. P. Fr. Alonso de Orozco, su confesor, y presentada en el proceso de Salamanca. Publicada en "Revista Agustiniana", vol. 1-2 (1881), p. 8791,

67. RoJAs, H. de, Relación... 1.c., p. 88. 
-No es razón que vos seais fraile, porque nuestros padres no reciban disgusto, pues no le queda ningún otro hijo varón, Alonso, todo decidido, le replicó:

-Hermano Francisco, salvémonos nosotros; que Dios tendrá cuidado del consuelo de nuestros padres.

En la Real Academia de Bellas Artes de San Fernando de Madrid se conserva un cuadro, que lleva la firma de Bartolomé González, pintor de la Corte de los Austrias Menores, y que perteneció al convento de San Agustín de Salamanca, donde aparece Fray Alonso de Orozco recibiendo la profesión de manos de santo Tomás de Villanueva, y a su lado el maestro de novicios, Venerable Fray Luis de Montoya. Al pie, una inscripción en la que se puede leer, traducido al castellano, "tan santo el novicio, como el prior y el maestro". Todo un símbolo.

Efectivamente, Fray Alonso de Orozco profesó de fraile agustino en el convento de Salamanca el día 9 de junio de 1523.

Cabe suponer que nuestro joven e inteligente religioso aprovechara bien el tiempo en sus estudios, preparándose debidamente para el sacerdocio, según los deseos de sus piadosos padres, y según aquello que dejara escrito el célebre Mabillón en sus Estudios Monásticos, que el buen religioso, de no ser corto de ingenio, saldrá por fuerza aventajado en las letras ${ }^{68}$.

Los biógrafos señalan que, una vez profeso, se dedicó al estudio de las Artes y de la Teología en la misma Universidad de Salamanca; de suerte que, enlazando estos estudios con los cursos de Derecho, que parece tenía ya aprobados antes de entrar en religión, dio cima a una brillante carrera eclesiástica; cosa que, por otra parte, es fácil de demostrar con sólo hacer una reseña de las obras que escribió, las cuales demuestran sus profundos conocimientos en los distintos ramos del saber humano, de modo especial en las ciencias sagradas.

Juan Márquez añade que, como el Señor le tenía escogido "para capellán de la Reina de los ángeles, habiendo comenzado sus estudios y servido algunos años en los ministerios en que se suelen ocupar los nuevos profesos, parecióle a la religión promoverle a la dignidad del sacerdocio" ${ }^{69}$.

68. Jean Mabillon fue un gran erudito francés del siglo XVII --"le grand siècle" de los franceses-, monje benedictino y autor, entre otros libros, del Tratado sobre los estudios monásticos; libro que escribió a su regreso de un viaje por Italia en 1685, en contra del fundador de los monjes trapenses, el abate Rancè, defendiendo la tesis de que los monjes benedictinos tenían perfecto derecho y debían cultivar los estudios.

69. MÁrquez, J., Vida del Venerable Padre Fray Alonso de Orozco, Madrid 1648, t. III, cap. IV, p. 7. 
Llegada la hora suprema, el propio Orozco nos la describe con las siguientes palabras: "Ordenándolo Vos por mis prelados, subí al estado tan alto del sacerdocio, del cual se admiran todos los espíritus celestes, viendo que unos hombres mortales tengan tan admirable poder de consagrar vuestro santísimo Cuerpo y Sangre, y que encierren en su pecho al que no cabe en el mundo... ${ }^{70}$.

Y recordando luego la quietud del alma en que ésta entraba, después de celebrar el santo sacrificio del altar, escribe: "Los sacerdotes, después de haber dicho misa, se retraen a contemplar en su pecho y paraíso a su Redentor, y a pedirle mercedes, pidiéndole entonces que si la vida fuere tan larga que llegara a otro día, quede aceptado el convite para el santo altar. Y confiados en un sí que el alma oye en espíritu, quedan muy consolados, y guardan su boca de palabras ociosas, y oran y leen como quien espera con hambre, lavadas las manos, para sentarse a tal mesa" ${ }^{71}$.

Fray Alonso de Orozco, sacerdote, de alma misionera, se sentía avergonzado, viéndose sosegado y tranquilo en los conventos españoles, donde la obediencia le había destinado y ocupado en prelacías que chocaban con su humildad. Se había forjado en el yunque misionero de santo Tomás de Villanueva, que fue quien envió la primera barcada de agustinos a la Nueva España en 1533, y había visto partir hacia el Nuevo Mundo a aquellos compañeros suyos, que habían hecho con él el noviciado en Salamanca ${ }^{72}$. Había llegado a una madurez personal y adquirido una ácida y dulce experiencia de las cosas que convertía a su juicio en seguridad, y en ordenada su voluntad. Había llegado a ese momento de la vida de un hombre en que se sabe dominar los nervios, que es una de las más grandes sabidurías humanas. Pensando en las misiones de América, volvía como al alba de su juventud; que era como volver al alba de sus ilusiones. Y después de meditarlo mucho ante el Señor, se atrevió a pedir a los superiores le dejaran partir para el Nuevo

70. Orozco, A. de, Confesiones, l.c., lib. III, cap. V, p. 68. $61)$.

71. Orozco, A. de, Regla de Vida cristiana, Doc. V, tom. II,, p. 392 (cf. CAMARA, T., o.c.,

72. Entre estos misioneros de primera hora, que envió Fray Tomás de Villanueva siendo Provincial, está el célebre Agustín de Coruña, natural del pueblo soriano Coruña, del obispado de Osma, y que profesó de agustino en el convento de Salamanca el 24 de junio del año 1524, en manos de santo Tomás de Villanueva, como lo hiciera el beato Alonso de Orozco.

En 1533, llevado de su fervor religioso, se alistó en la primera misión de agustinos que, presidida por Fray Francisco de la Cruz, pasó a la Nueva España, donde trabajó incansablemente por la conversión de los nativos, siendo un gran defensor de sus derechos en contra de los negreros y de cuantos abusaron de su ignorancia y fiel servidumbre. Mucho se ha escrito y mucho queda por escribir sobre esta excelsa figura de la Orden de san Agustín y de la Iglesia universal. Nos remitimos al P. Gregorio de Santiago Vela, en su monumental Ensayo de una Biblioteca Iberoamericana, vol. II, p. 149 y ss. 
Mundo en una nueva travesía de misioneros agustinos. Los superiores le dieron licencia, pero el Señor se la negó. Cerca de las islas Afortunadas, cayó enfermo y los médicos le aconsejaron que desembarcara, pues era temerario proseguir el viaje. Esto ocurría el año 1548.

Fray Alonso de Orozco se quedó en las Islas Canarias, mientras el barco, llevando a bordo a sus compañeros, siguió rumbo a Nueva España. El Señor le reservaba para otra misión, aceptando solamente el sacrificio de sus deseos y probando, al mismo tiempo, la fidelidad de su amigo.

Él, reconociéndolo así, pudo escribir: “¡Oh secretos vuestros profundos! De tal manera me cortasteis el hilo, que los médicos, desconfiando de mi vida, dijeron que en ninguna manera debía pasar adelante; y que si no entrara en la mar, que no volviera aqueıน enfermedad la segunda vez ${ }^{73}$, de manera que aún no del todo libre de los dolores, hube de navegar para España. Por todo seais Vos loado, que ha ya más de treinta años que ningún rastro de aquella enfermedad he sentido. Escrito está que no hay riqueza que exceda al valor de la salud; mas yo por mayores bienes tengo de vuestra bendita mano dados la experiencia de dolores en esta vida, que Vos dais a quien por vuestro amor les desea sentir" ${ }^{74}$.

Quien haya visitado el Museo Oriental de PP. Agustinos de Valladolid y entretenido un momento por los claustros neoclásicos de Ventura Rodríguez, habrá podido contemplar un hermoso lienzo, obra del agustino Víctor Millán, en que aparece el Beato Alonso de Orozco postrado de rodillas y en lo alto la imagen de Nuestra Señora encomendándole que escribiese. "Escribe, Alonso -le dijo-, escribe".

Efectivamente, estaba de prior en Sevilla cuando recibió aquel encargo, que es de mucho agradecer, pues gracias a eso, Fray Alonso de Orozco está hoy en el catálogo de los Autores de la Lengua y nos ha dejado libros tan hermosos como Vergel de Oración y Monte de Contemplación; y tras éste, otros en romance, como Memorial de amor santo; Regla de vida cristiana; Examen de la conciencia; Ejercitatorio espiritual; Soliloquios de vuestra sagrada Pasión; Victoria del mundo; Arte de amar a Dios; Historia de la Reina de Saba; Epistolario cristiano; Tratado de las siete palabras de María Santísima; Catecismo provechoso; Libro de la suavidad de Dios; Tratado de la Corona de Nuestra Señora; Guarda de la lengua...; sin contar los que se refieren expresamente a la historia de la Orden Agustiniana y a los numerosos tratados que escribió en latín ${ }^{75}$.

73. La primera vez que cayó enfermo de gravedad Fray Alonso de Orozco, y a la que se refiere en estas palabras, fue residiendo en el convento de Sevilla en 1540.

74. Orozco, A. de, Confesiones, l.c., lib. III, cap. IV, p. 65.

75. Para la bibliografía del beato Alonso de Orozco, puede consultarse a Gregorio de Santiago Vela, Ensayo..., vol. VI, p. 96-169. 
Cuando el propio P. Orozco haga una recopilación de sus escritos, escribirá al final de la misma: "Todo esto escribí por mandado de vuestra Santísima Madre, a quien Vos, Señor, siendo de doce años, obedecisteis, y los ángeles se tienen por dichosos en obedecerla".

Sebastián Portillo y Aguilar, uno de tantos biógrafos que se ocuparon del P. Alonso de Orozco, resume así los cargos en que le ocupó la obediencia: "Fue prior de Soria, de Medina del Campo, de Granada: Visitador de los conventos de Canarias; Presidente de un Capítulo; dos veces Definidor; prior de Valladolid; y últimamente primer rector del colegio de doña María de Aragón" ${ }^{76}$.

Si nos acercamos a la histórica villa de Medina del Campo, donde en 1504 muriera Isabel la Católica, todavía podemos contemplar las huellas -ruinas de un glorioso pasado- de un claustro por donde paseaba nuestro agustino, siendo superior del convento por el año 1541, y donde el Señor le sometió a una dolorosa prueba, según nos cuenta en el citado libro de sus Confesiones. "Aquí, Rey poderoso, tengo yo que daros muchas gracias, que me pasasteis por agua y fuego, dándome todas estas maneras de trabajos en el cuerpo y en el alma. No sólo me librasteis de aquel peligro, cuando me ahogaba en el río de Talavera ${ }^{n}$, y me disteis salud en la enfermedad grave cuando era de diez años; más aún, ya siendo religioso y bien de treinta años, en nuestro monasterio de Medina del Campo estuve desahuciado de los médicos..." 78 .

Después de residir en los conventos de Andalucía hasta el año 1550, el Beato Orozco regresó a Castilla y lo encontramos en Valladolid, de superior del convento de San Agustín en el año 1551. La ciudad del Conde Ansúrez pasaba entonces por unos momentos de gloria y esplendor que sólo volvería a gozar a comienzos del siglo XVII, cuando Felipe III, mal aconsejado por su valido el duque de Lerma, decidió trasladar nuevamente la corte desde Madrid a la antigua e histórica ciudad castellana.

76. Portillo y Aguilar, S. de, Vida del Beato Alonso de Orozco. en Manuel Vidal, Agustinos de Salamanca, lib. III, cap. XII, p, 386.

77. Efectivamente, cuenta en sus Confesiones que, siendo niño, de solos diez años de edad, y residiendo ya en Talavera de la Reina, paseando un día a orilla del río, un mancebo le invitó a que se metiera dentro del agua, pues no corría peligro alguno. "Yo creíle -escribe-, y en alargando el paso, hundíme, que estaba hondo. Llevábame la corriente del agua más adentro, y con la congoja de sentirme ahogar, dieron gritos unas mujeres, que lavaban paños, a este mancebo, que no tenía más de la capa cubierta, que entrase a remediarme, y trabando de las aldas de mi sayo, que andaba sobre el agua, sacóme de aquel peligro. Luego en esta hora entró otro mancebo a nadar, y en el mismo lugar se ahogó, avisándole antes de lo que a mí me había acaecido" (Cf. Orozco, A. de, Confesiones, lib. II, cap. $1^{\circ}$, p. 38).

78. Orozco, A. de, Confesiones, l.c., lib. II, cap. 11, p. 49. 
En el libro que publicó el Ateneo vallisoletano, el año 1981, sobre Valladolid en el siglo XVI, se la llama "Corazón del mundo hispánico" ${ }^{79}$. Sede del Consejo Real, tras las Cortes celebradas por Carlos V en 1518, durante la "Guerra de las Comunidades", desempeñó un importante papel entre los comuneros; por lo que, al ser vencidos éstos, Carlos V desposeyó a la capital de los amplios privilegios de que gozaba.

Sin embargo, aquí habría de nacer a los pocos años el príncipe heredero don Felipe, y aquí habría de presidir doña Juana de Austria, infanta de España, hija de Carlos V y de Isabel de Portugal, casada con su primo el infante don Juan Manuel, heredero del trono portugués y madre del desafortunado rey don Sebastián, Regente de España y Gobernadora en ausencia de su padre y de su hermano don 1 clipe, los célebres autos de fe, celebrados contra el doctor Cazalla, que murió en la hoguera, habiendo sido, años atrás, capellán del propio Emperador Carlos V y uno de sus predicadores favoritos ${ }^{80}$.

El Valladolid que conoció Fray Alonso de Orozco era la capital comercial y artesanal de Castilla, donde se vendían paños, sedas, platerías -ahí está, como en el recuerdo, su famosa calle-, y que contaba con las mejores imprentas de España, testimonio vivo de su floreciente cultura.

Residiendo en Valladolid nuestro agustino, recibió -el 13 de marzo del año 1554- el albalá, firmado en Bruselas por Carlos V, por el que se le nombraba predicador real.

En el Capítulo provincial de 1557, que tuvo que presidir por muerte del primer definidor, P. Francisco de Nieva, y que se celebró en el convento de Dueñas, salió elegido nuevamente prior del monasterio vallisoletano.

Herrera cita los religiosos que profesaron en sus manos, durante su gobierno; algunos de ellos, beneméritos e ilustres misioneros en tierras de América. Destaca el P. Andrés de Villarreal, el cual llegó a ser Provincial de la Provincia agustiniana del Perú el año 1582, y del que el cronista peruano Antonio de la Calancha dice que era hijo de la provincia de Castilla, "donde

79. Valladolid "Corazón del mundo hispánico". Siglo XVI. L. A. RiBOT y otros autores. Ed. Ateneo de Valladolid 1981.

80. Agustín Cazalla, nacido en 1510 y muerto en Valladolid el 1559, estudió en la ciudad del Conde Ansúrez, donde tuvo por maestro a Bartolomé Carranza, y más tarde en la Universidad de Alcalá, donde se graduó el año 1530. Fue capellán de Carlos V y uno de sus predicadores favoritos, acompañándole en sus viajes a Flandes y Alemania, hasta que en 1552 obtuvo una canonjía en Salamanca, quedándose definitivamente en España.

Al parecer, era un erasmista que había evolucionado hacia el luteranismo, convirtiéndose en el centro de un foco protestante en la citada ciudad de Valladolid. En 1558 fue juzgado con una severidad desusada anteriormente, y condenado a morir en un auto de fe, si bien el hecho de haberse reconciliado, le valió el ser estrangulado antes de ser entregado a las llamas. 
era tenido por ejemplar religioso y muy amante de la paz entre sus hermanos que procuró fomentar siempre".

Había llegado al antiguo imperio de los Incas en la segunda misión enviada por los agustinos españoles, el año 1557. Fue maestro de novicios en el convento de Lima, prior y visitador del Cuzco, Definidor y uno de los primeros presentados de la Provincia.

El citado cronista peruano dice que duró poco tiempo su acertado gobierno, pues a fines del 1583 falleció santamente en Trujillo, estando girando la visita que mandaban los cánones ${ }^{81}$.

En Valladolid, el P. Alonso de Orozco se convirtió en el consejero y confidente de la citada doña Juana de Austria, y a ella dedicó su hermoso libro Tratado de las siete palabras que María Santísima habló, que salió a la luz pública el año $1556^{82}$. La dedicatoria habla por sí sola y expresa la devoción que tenía el agustino por la princesa doña Juana: "a la muy alta y muy poderoso señora Doña Juana, Infanta de Castilla y Princesa de Portugal, gobernadora de estos reinos de España...".

"El año pasado ofrecí de mi pobreza a vuestra Alteza -le dice- la Recopilación de nuestras seis obras ${ }^{83}$, enmendadas de nuevo, aunque ya antes impresas, en las cuales, sabiendo yo que se emplea algún tiempo, leyendo con aquel gusto que nuestro Dios suele dar en su divina palabra al alma que la desea y ama; parecióme ofrecer de nuevo esta declaración de las siete palabras de la Reina del cielo, Madre de Dios, las cuales en este nuestro monasterio de San Agustín (de Valladolid), con el favor del Espíritu Santo, los sábados de la Cuaresma prediqué para honra de la Princesa del mundo, Virgen María" ${ }^{84}$.

Trasladada la Corte a Madrid, después de las desastrosas ferias y del voraz incendio de 1561, el P. Alonso de Orozco se vio obligado a seguirla hasta lo que iba a ser desde entonces la capital de España, escogiendo para

81. Calancha, A. de la, Crónica moralizada de la Orden de San Agustín en el Perú, Barcelona 1639 , lib. II, cap. 16, p. 399.

82. En Gregorio de Santiago Vela vemos citado este libro del modo siguiente: "Obra nueva, y muy provechosa que trata de las siete palabras que la Virgen sacratísima Ntra. Señora habló. Decláranse en siete sermones. Hecho por el muy Reverendo padre Fray Alonso de Orozco, de la Orden de San Agustín, predicador de su Majestad, etc. Visto y examinado, y con licencia impreso. En Valladolid. En este año de 1556. (Cf. SANTIAGo Vela, G. de, Ensayo, vol. VI., p. 118).

83. Efectivamente, el año 1554, el Bto. Alonso de Orozco hizo una Recopilación de todas las obras que había publicado hasta entonces, "agora nuevamente corregidas por el mesmo autor", según leemos en la portada, y que imprimió en Valladolid, con hermosa dedicatoria "a la muy alta y muy poderosa señora doña Juana de Austria".

84. Orozco, A. de, Obra nueva y muy provechosa, etc., Cf. SANTiAgo Vela, G. de, Ensayo, vol. VI, p. 118. 
su morada la celda más oscura, más pobre y más incómoda del convento de San Felipe el Real, famoso en la historia de la literatura española, pues en su escalinata o gradas tenía lugar el célebre mentidero madrileño, donde don Luis de Góngora, don Francisco de Quevedo, Lope de Vega, Juan de Alarcón, Luis Vélez de Guevara y tantos otros ilustres literatos se saludaban, y no siempre con palabras de amistad y cariño.

En Madrid y en el convento de San Felipe permaneció hasta los últimos días de su vida, en que doña María de Aragón le llevó, para ser mejor atendido y cuidado por ella, al colegio que lleva su nombre, fundado por nuestro agustino y gracias a la generosidad y mecenazgo de esta bondadosa señora y dama de la reina doña Ana de Au: "ria, madre de Felipe III.

La citada princesa doña Juana, mientras ésta estuvo al frente de los destinos de España como gobernadora, en ausencia de su padre y hermano, no solamente le tomó por confesor y consejero, sino que le nombró testamentario, junto con el P. Juan de Vega.

Fray Alonso de Orozco se nos ha ido de Valladolid a la capital de España. Aquí, a pesar de ser el capellán de palacio, amado y querido de todos, llevará una vida de fraile sencillo, humilde y penitente; alejado del fausto, del incienso y de la vanidad que siempre trae consigo el vivir en palacio, al que solamente acudía cuando era reclamado su servicio obligatorio, o su caridad.

Por fuerza, tenía que encontrarse un tanto cansado de la Corte y de los honores que en ella recibía. Solía decir a menudo: "esta dura cárcel de vivir entre el ruido y los cumplimientos de la corte es apenas tolerable".

Hombre de oración y profunda vida interior anhelaba otra vida más recogida y silenciosa, "lejos del mundanal ruido", que diría el Mtro. León. Anhelaba la soledad y el silencio de algún convento que estuviera alejado de Madrid. “ ¡Oh desierto santo! -dejará escrito- ¡Oh lugar cercano a la corte celestial! ¡Oh dichoso el que es llevado de Dios para morar en ti!, y como otro san Juan Evangelista en la isla de Patmos, ver abierto el cielo, gozar de visitaciones de ángeles... Por entender estos secretos, la esposa suplicaba con gran instancia y decía: Amado mío, esposo, vámonos al campo" ${ }^{85}$.

Llegó el día en que, suplicante y siempre servidor, le pidió al rey le dejara partir al apartado convento de Nuestra Señora del Risco, situado en lo más fragoso de la sierra de Ávila, lugar más propio para nido de águilas, que para morada de los hombres ${ }^{86}$.

85. OROzCO, A. de, Vidas y martirios de los bienaventurados S. Juan Bautista y Juan Evangelista. Cf. CAMARA, T., o.c., lib. II, cap. XVI, p. 237.

86. El origen de este monasterio arranca de la ermita que el P. Francisco Parra había levantado en honor de la Virgen. (Cf. VIDAL, M., Agustinos de Salamanca, t. I, lib. $2^{\circ}$, p. 136). 
- Señor -le dijo, entrando una mañana en la cámara regia-, he vivido muchos años en la corte y no sé cómo los he gastado. Por otra parte, soy muy viejo y necesito prepararme para la muerte. Déjeme V.M. retirarme a un convento que nuestra Religión tiene en el Risco.

Pero Felipe II no estaba por la función, aunque su devoto capellán se lo pidiera de rodillas, como de hecho se lo pidió por dos veces, según testimonio de los religiosos que siempre le acompañaban a palacio y que más tảrde declararon en el Sumario para el proceso de su beatificación.

Ya se ve que el rey más poderoso de la tierra necesitaba del más pequeño y humilde de cuantos religiosos tenía en la corte.

Fray Alonso de Orozco, resignado, se contentará con decir: "A no ser por la obediencia ya hubiera rompido (sic) por todo y hubiera huido de la corte" ${ }^{87}$.

La venganza que tomará este siervo de Dios y servidor de los hombres será repartir a manos llenas su caridad entre los pobres y necesitados; predicar la Palabra a pobres y ricos con verdad y sinceridad; visitar las cárceles y los hospitales; fundar conventos donde se observe la más estricta y rigurosa disciplina monástica; recogerse por las noches en oración; escribir libros de ascética y mística; ser, en fin, el buen pastor y mejor samaritano del Evangelio en toda la extensión y realidad de estas palabras.

Los testimonios son abundantes y los biógrafos los relatan hasta la saciedad $^{88}$.

Mucho le estimaba la princesa doña Juana. Pero quien de verdad quería verlo siempre a su lado era el príncipe, más tarde rey, don Felipe II, el cual debió sufrir mucho con el terrible incendio citado que asoló a la ciudad, donde había nacido, el año 1561, por las fiestas de San Mateo, patrono de la misma. Acababa de contraer nuevas nupcias -eran las terceras- con la hija de Enrique II de Francia, doña Isabel de Valois -"la esposa más amada"-, en Guadalajara. Hacía poco que había regresado de los Países Bajos, y estaba decidido a trasladar la corte a la villa de Madrid; lo que no dejó de causar extrañeza; decisión en la que debió influir, aparte el temperamento sedentario del monarca, la complicación creciente de los organismos administrativos, ya que la burocracia castellana había llegado a un grado de perfección no igualado entonces por ninguna nación europea.

87. En su Epistolario cristiano dejará escrito: "La voluntad de Dios es buena, apacible y perfecta. El probarla es gustarla, saborearnos en ella; y esto no se puede hacer sino negando la nuestra" (Cf. Orozco, A. de, Epistolario cristiano, l.c., p. 195.

88. Sobre el particular, puede consultarse la sabrosa y estupenda biografía del Ilmo. P. Tomás Cámara. 
Este rey, dueño entonces del mundo, en cuyos dominios no se ponía el sol y ante quien temblaban los grandes de España ${ }^{89}$, escuchaba con devoción al P. Orozco, que le hablaba -escriben los biógrafos- con santa libertad y mucha franqueza en punto a las obligaciones graves de su estado; de modo especial, las que tenía como monarca cristiano.

Tal vez, para que no olvidara sus consejos, escribió un libro dirigido a él personalmente, con dedicatoria hermosa y ejemplar. Se trata de una obra escrita primeramente en latín, que deseó luego traducir al castellano, pero que solamente hizo un compendio, que va al final de la misma y salió ya en la primera edición de 1565, impresa en Alcalá de Henares ${ }^{90}$.

Tal vez, pensando en lo difícil que lo tenía el monarca español y lo que el devoto capellán sabía acerca de los problemas existentes con el príncipe don Carlos, escribió otro libro, éste en perfecto castellano, dedicado personalmente al malogrado príncipe ${ }^{91}$, y que se titula Epistolario cristiano, donde, aparte la carta que dirige a don Carlos, encontramos otra dirigida "a un Obispo de las Indias", y que no es otro que su compañero y connovicio Fray Agustín de Coruña, junto con las que dirige "a un señor de vasallos", "a un sacerdote eclesiástico", "para un religioso", "para una religiosa", etc. La última de ellas, que hace el número trece, que es la de la Virgen, va dirigida a san Ignacio mártir, discípulo de san Juan Evangelista.

El rey sabía agradecer todas estas atenciones y le consultaba en los negocios más arduos de la corona, sobre asuntos familiares y, también, sobre el modo de promover la salud y el mayor bienestar del pueblo. "Creedme, hermano -escribe Fray Alonso en el citado libro Regalis Institutio-, que si el que gobierna no se humilla a tomar consejo, va perdido, y su república ten-

89. Se cuenta que el gran Duque de Alba, ganador de cien batallas, hombre indomable y duro, Gobernador de Flandes, donde no ha dejado un buen recuerdo, pero acaso el más grande de los generales que tuvo Felipe II en su largo reinado, al entrar en presencia de este monarca para dar cuenta de sus gestiones al frente de sus diversos cometidos, temblada como un niño, y no conseguía serenarse hasta tanto que el rey, extendiendo complacido la mano, le decía: "¡serenaos, señor!".

90. Nicolás Antonio dice que el P. Alonso de Orozco tradujo este libro y se imprimió el mismo año en Alcalá. El Beato prometió, a lo que parece, traducirlo, pero no lo efectuó, como anotaron los editores de la edición grande de sus obras del siglo XVIII. Hizo, sí, un compendio de la Institución en romance, que va al final de la obra, y salió todavía en la primera edición de ella, Nicolás Antonio, no obstante, distingue el tamaño de una y otra, poniendo en $4^{\circ}$ el de la edición latina, y en $8^{\circ}$ el de la castellana; lo cual pudiera inducir alguna sospecha de que, en realidad, no solamente llevó a cabo el trabajo de la versión, sino que llegó a editarlo (Cf. SANTIAGo VelA, G. de, Ensayo, vol. VI, p. 121).

91. Orozco, A. de, Epistolario cristiano, para todos los estados, compuesto por el reverendo Padre Fray Alonso de Orozco, Predicador de su Majestad, de la Orden de San Agustín. Dirigido al muy poderoso Príncipe de España Don Carlos. Impreso en Alcalá, en casa de Juan de Villanueva. Año de 1567. 
drá grandes trabajos... Que mejor se rige un reino por un prudente Príncipe, que por muchos gobernadores. Esto enseña claro la experiencia, pues en toda la república de tantos sentidos, un ánima es la que rige; y en este universo, uno es el que mueve, y no es movido, nuestro Dios soberano, que todo lo gobierna; al cual llamaron los filósofos Causa Primera".

Y esto que hacía con el monarca, trataba de conseguirlo también con los grandes de España, así eclesiásticos, como nobles seglares. De hecho, su nuevo libro Arte de amar a Dios y al prójimo lo dedicará a su amigo íntimo, cardenal Espinosa, Presidente del Consejo de Castilla ${ }^{92}$, con una dedicatoria que es todo un mensaje del amor y ternura que los nobles y grandes de la tierra deben tener hacia los pobres y más necesitados del Reino. "Porque las dignidades grandes de esta vida -escribe el P. Orozco en un bellísimo castellano- son como los árboles plantados en altos montes, los cuales de todas partes son combatidos de vientos bravos: teniendo los árboles puestos en valle profundo gran quietud, en aquel mismo tiempo que el aire menea y combate los que están en alto".

Con seguridad que el cardenal Diego de Espinosa tuvo en cuenta aquellos sabios consejos, pues se cuenta que, contemplando don Felipe II el sepulcro de este prócer español, exclamó: "Aquí está enterrado el mejor ministro que he tenido en mis coronas". El cardenal Espinosa había muerto el año de 1572 en Madrid.

Pero donde el $\mathrm{P}$. Orozco tenía sus delicias era entre los pobres y enfermos de los hospitales y cárceles de Madrid. Sobre el particular, el biógrafo Márquez cuenta que, así como no consentía que entrara ningún fraile en su celda, ésta "no se vaciaba de esta gente abandonada de la fortuna". Lloraba el siervo de Dios, al comprobar que los pobres se morían de frío por las calles de Madrid en los días más crudos del invierno castellano y cuando él salía por las mañanas a hacer sus ministerios sacerdotales. Y tomándoles de la mano, les hacía entrar en alguna casa, al tiempo que encargaba a la dueña: "Pongan a este ángel al lado del brasero y dénle algo de comer".

92. Orozco, A. de, Arte de amar a Dios y al prójimo. Imp. Hernán Ramírez, Alcalá de Henares 1585.

Sobre este personaje, Diego de Espinosa, tenemos que decir que era natural del pueblo de Martín Muñoz de las Posadas, donde había visto la luz primera en el 1502, para morir en 1572 en la villa y corte de Madrid. Era de familia noble, mas venida a menos. Fue profesor de Derecho en la Universidad de Salamanca, Oidor en Sevilla y Regente del Consejo de Navarra. El rey Felipe II le distinguió con su confianza, nombrándole sucesivamente Presidente del Consejo de Castilla, Inquisidor general en sustitución de Valdés, jefe del Consejo de Estado y jefe, igualmente, del Consejo privado. Fue obispo de Sigüenza, y el papa Pío V le nombró cardenal el año 1568. Su actuación ha sido muy discutida; de modo especial, en su calidad de presidente del Consejo de Castilla, cuando aconsejó la publicación del decreto que provocó la revuelta morisca de 1568. Fue entonces cuando perdió el favor del monarca, muriendo al poco tiempo. 
Personalmente, remediaba con sus limosnas a cuantos podía. Medina, uno de los testigos que le acompañaba cuando salía de casa, cuenta que gastaba en limosnas "todos los gajes que tiraba de su Majestad (el dinero que recibía como capellán de la Corte); y pedía a otras muchas y diferentes personas de la Corte; y todas las empleaba con huérfanas y viudas, en vergonzantes y doncellas pobres; y muchas y diversas veces le vi hacer capotillos y gregüescos para los pobres de la portería".

Era tanta la caridad que tenía con los pobres -declara una dama de la Corte, por nombre doña María de la Columna-, "que hasta se proveía de carbón en el invierno, y lo encendía cada mañana en la portería del convento, y los pobres le estaban aguardando para calentarse" ${ }^{93}$.

Con los enfermos extremaba su caridad. Los jóvenes agustinos que le acompañaban a los hospitales, declaran en el proceso de su beatificación que, según iban de camino, el P. Orozco compraba bizcochos, pasas y otros regalos para entregarlos después a los pacientes que visitaba. "Con estas cosas caminaba a un hospital -dice uno de ellos- y entraba en la enfermería donde estaban los pobres; y comenzando desde la primera cama, se hincaba de rodillas y, juntas las manos, con los ojos levantados en espíritu, hacía oración; la cual acabada, decía al enfermo los evangelios y, haciendo la señal de la cruz en la parte dolorida, le ponía luego sus manos, le consolaba y animaba en Dios; y luego le repartía los bizcochos y regalos que llevaba este testigo en la cestilla, y con sus manos se los ponía debajo de la almohada; y más: le daba en dinero limosna envuelta en un papel, para que nadie echase de ver lo que daba. Y esto que tengo dicho que hacía con el primer enfermo, lo hacía con cada uno de ellos, sin dejar a ninguno; y a los que no alcanzaban los bizcochos, les daba dinero... Y lo que arriba se dice, le sucedía en todos los demás hospitales; porque un día visitaba uno, y otro día a otro, sin dejar a ninguno" 94 .

Otro tanto hacía con los presos de las cárceles. Uno de los testigos, Francisco López Salgado, platero de palacio, gran amigo del P. Alonso de Orozco, declara que, en los treinta años que le conoció, le daba con frecuencia dineros "para que fuese a la cárcel de esta villa (Madrid) y sacase los presos que estuviesen detenidos por las costas".

Así era este hombre: sencillo, generoso, caritativo, bueno de verdad para con todo el mundo. "iSi pudiese yo poner mesa a todos los pobres por vuestro santísimo amor, Señor! ¡Si visitase todos los hospitales y sirviese a los enfermos, rescatase los cautivos, vistiese los desnudos, aposentase todos

93. Declaración de doña María de la Columna, en el Informe Sumarial de Madrid, fol. 345.

94. Informe Sumarial de Madrid, fol. 214. 
los peregrinos y diese sepultura a todos los que son difuntos! ¡Cuán dichosa sería mi alma, Señor" " -escribía nuestro agustino en su libro Exercitatorio espiritual $^{95}$.

Y llegaron los calurosos días del mes de agosto en la capital de España. El P. Orozco contaba ya los noventa y un años de edad y padecía fuertes calenturas. Se nos moría. Para él, se acercaba la hora del descanso definitivo. Antes de que la muerte llamara a las puertas de su vida, tuvo el consuelo de ser visitado por el también anciano y enfermo de gota, Su Majestad el rey Felipe II, acompañado del príncipe y de la infanta doña Isabel Clara Eugenia, que mucho le querían. No contento con esta visita, el monarca, encontrándose por aquellos días en El Escorial, enviaba "todos los días un médico de cámara", con el fín de que luego le diera relación del estado del enfermo.

El día en que el cardenal Quiroga, arzobispo y primado de Toledo, le fue a visitar, al tiempo de la despedida, el P. Orozco le pidió la bendición. Pero el ilustre purpurado, todo confuso, en lugar de hacerlo, se atrevió a pedir encarecidamente la suya. La disputa terminó con la mutua manifestación de devota amistad ${ }^{96}$.

Uno de los presentes a los últimos instantes del P. Orozco ${ }^{97}$, viendo éste cómo se les saltaban las lágrimas a todos los hermanos que rodeaban su lecho, les dijo con gran dulzura:

-Sosiéguense, hermanos, y no se alboroten, que hasta mañana al mediodía yo confío en Dios que no me tengo de morir ${ }^{98}$.

Amaneció el 19 de septiembre de 1591. Era jueves, como bien apuntan los biógrafos. El P. Orozco, muy sereno, la mente lúcida del todo, pidió que le trajeran su amada compañera: la cruz desnuda. Se abrazó a ella, la besó repetidamente y se atrevió a pedirle que le guiara, por fin, a las playas de la verdadera patria. Segundos más tarde, expiró.

El sol otoñal, claro y luminoso, de la villa y corte de Madrid llegaba a su cénit. Los relojes de arena de palacio marcaban las doce del mediodía.

Al día siguiente, en las solemnes exequias, celebradas en la iglesia de la Encarnación, el ilustre predicador y dignísimo arzobispo de Zaragoza, el agustino Fray Pedro Manrique, pronunció estas sencillas palabras: “ ¡He ahí al hombre! ¡He ahí al santo! Fue fraile entre nosotros setenta y tantos años,

95. Orozco, A. de, Exercitario espiritual, t. II, p. 414. Ed. de Madrid, 1585.

96. Esta escena la cuenta el P. Matías Oliveros, testigo presencial de la misma, toda vez que era entonces enfermero del Venerable (Cf. Informe Sumarial de Madrid, fol. 543).

97. El P. Alonso del Rincón, que era natural de la villa madrileña de Valdemoro, y que había profesado en el convento de San Felipe el Real el día 31 de enero de 1591, justamente el año en que murió el P. Alonso de Orozco.

98. P. Alonso del RinCón, Informe Sumarial de Madrid, fol. 652. 
sin queja de nadie, con edificación de muchos y con espanto de todos. Hombre de nuestra naturaleza, vestido de las condiciones de ella, criado entre nosotros debajo de nuestro hábito; y tras eso, vernos y verle, ponía grima el pensarlo...".

"He aquí el triunfo de la santidad -escribe el docto P. Tomás Cámara-. Si esas prendas (reliquias), y mayormente el cadáver, pertenecen a un difunto común, aun de un amigo, no se tocan sin respeto frío, o sin pasmo y horror; y porque son de un santo, ajadas y deslustradas en sí, la imaginación las embellece con el colorido más hermoso; con los aromas de flores de otra primavera que anhelamos, y las abraza, y las besa afectuosamente. El triunfo en esta parte del Beato Orozco no pudo ser más completo; si como santo había sido aclamado y bendecido en vida, el lector acaba de leer lo que aconteció en su muerte. ¿Ubi est mors victoria tua? ¿Dónde, oh muerte, está tu victoria?".

Así es, en efecto. Mas con todo, lo importante aquí es el hombre de Dios, el ejemplo vivo de hermosas virtudes humanas, cristianas y religiosas, el padre de los pobres y limosnero de los necesitados, el consejero de príncipes; en fin: El hombre, el santo.

\section{Alonso DE OROZCO, DEFENSOR DE LA LENGUA CASTELlANA}

Es posible que, a excepción de Juan de Valdés, autor de Diálogo de la lengua ${ }^{99}$ y del propio Fray Luis de León ${ }^{100}$, el cual escribió en su libro De los Nombres de Cristo una brillante apología de la lengua castellana, pocos escritores españoles han superado y han mejorado, en este punto, en tiempo y calidad al P. Alonso de Orozco.

99. Juan de Valdés, humanista español, nacido en la misma patria chica del Mtro. León, Belmonte, y hermano gemelo de Alfonso de Valdés, de joven siguió las ideas iluministas y la doctrina de Erasmo, con el que llegó a mantener correspondencia. Denunciado a la Inquisición, huyó a Italia, donde sirvió al papa, y donde llegó a ser jefe espiritual de un pequeño núcleo aristocrático, al que también inquietaban las cuestiones religiosas. A su muerte, sus doctrinas fueron condenadas por heterodoxas, y algunos de sus discípulos se convirtieron al protestantismo. Juan de Valdés ha pasado a la posteridad, de modo especial, por ser el autor de Diálogo de la lengua, en el que, en forma dialogada entre dos amigos italianos, uno español y él mismo, hace un elogio de la lengua romance y aconseja el buen empleo de la misma.

100. Sobre el Mtro. León, como defensor de la lengua castellana, el P. Félix García ha dejado escrito que, por primera vez, se llega al propósito meditado de encauzar la lengua y convertirla en instrumento de arte y de belleza; "es decir, que encontramos ya expresa una voluntad de estilo. Él escoge las palabras, las cincela, las pulimenta, las acopla e hincha de sentido; las ordena y da gracia, con el dominio y responsabilidad con que un pintor escoge y combina los colores para producir la obra perfecta" (Cf. GARciA, F., Obras completas de Fray Luis de León. Ed. BAC, Madrid 1944, p. XXV). 
En su obra Tratado de las Siete Palabras que María Santísima habló, saliendo al encuentro de cuantos pudieran rasgarse las vestiduras por escribirla en lengua romance y no en latín, como era de rigor hasta entonces, declara paladinamente: 'No os dé pesadumbre, sabio lector, ir por vía de sermones este libro; pues no os la da oír cada día predicar. Sabed que San Crisóstomo, San Atanasio, San Basilio y otros doctores griegos de gran erudición y autoridad, en su vulgar (lengua) escribieron sus sermones y homilías, y después fueron traducidos en latín. Muchos predicadores italianos escribieron sermonarios en su lengua toscana. Cada nación usó mucho escribir su propia lengua. Solamente los españoles, amigos de trajes peregrinos y costumbres extranjeras, tenemos en poco lo que se escribiese en nuestra lengua, siendo la que más estimada debe ser en elegancia y perfección, después de la latina. De mí, digo que alabo al Señor cuando leo libros en romance de buena y provechosa doctrina. Mayormente que mi fin no es hablar en este libro con predicadores y personas sabias, de quien yo tengo de oír y aprender: a los pequeños deseo consolar y aprovechar, aunque bien me acuerdo que, leyendo Virgilio al poeta Ennio, de más bajo estilo entre los poetas, dijo a un amigo suyo: ando buscando oro en este polvo. No hay libro tan sin provecho, que no sea de grande utilidad al que es sabio, si quisiera leerle atentamente" ${ }^{101}$.

Muy equivocados anduvieron, en sus juicios valorativos sobre los escritos del P. Orozco, el escritor y crítico americano Ticknor ${ }^{102}$, el cual no había leído nada de nuestro agustino, y su traductor al castellano Pascual Gayangos, que solamente conocía muy por encima el Epistolario Cristiano para todos los estados; obra que califica como la más importante de su autor.

El que sí acierta plenamente es Juan Márquez, que sostiene cómo Orozco "no es inferior en romance y en latín a los que con mayor primor escriben en una y en otra lengua".

El P. Cámara trae una serie de textos, entresacados de las obras del asceta y místico agustino como prueba verídica de ello. "Andan la muerte y la vida como hermanas trabadas de las manos -escribe Fray Alonso de Orozco en su libro Victoria sobre la muerte-, y andamos todos como cercados de pies a cabeza de una serpiente que nos come y consume la vida. ¡Cosa de notar! Que, antes que venga el día de la natividad, ya la muerte ha comido el tiempo de nueve meses a cada uno de los mortales. Dime, hombre, que te

101. Orozco, A. de, Tratado de las Siete Palabras que María Santísima habló. Ed. Laurentino Herrán. Rialp, S.A., Madrid 1966, prólogo, p. 54-55.

102. TiCKnOR, J., Historia de la literatura española. Trad. de Gayangos y Vedia, vol. III, cap. 39. 
prometes largos años de vida y te parece que eres inmortal, ¿qué es de aquella niñez y edad de la inocencia? ¿Qué se hizo aquella flor de tu mocedad? No puedes negar que la sierpe, que traes enroscada en tu cuerpo; te la comió; pues esa misma te consumirá la vejez. Todos nos estamos muriendo, y como el agua de los ríos va con ímpetu a la mar, caminamos sin detenernos para la sepultura, a quien llama madre el santo Job, la cual tiene los brazos abiertos para recibirnos. O como dijo poéticamente Andrada:

“¿Será que pueda ver que me desvío de la vida viviendo, y que está unida la cauta muerte al simple vivir mío?

Como los ríos en veloz corrida se llevan a la mar, tal soy llevado al último suspiro de mi vida.

De la pasada edad, ¿qué me ha quedado?

$\mathrm{O}$ ¿qué tengo yo, a dicha, en la que espero, sin ninguna noticia de mi hado?

¡Oh si acabase, viendo como muero, de aprender a morir antes que llegue aquel forzoso término postrero!" ${ }^{103}$.

Resulta curioso observar cómo Fray Alonso de Orozco conocía al poeta portugués Francisco de Andrada, autor del poema titulado "O primeiro cerco de Diu", impreso en Lisboa el año 1589, pero que sin duda ya corría en los círculos literarios anteriores a esta fecha ${ }^{104}$.

Lo mismo podría haber citado las célebres Coplas de Jorge Manrique, que con toda seguridad conocía:

"Nuestras vidas son los ríos que van a dar en la mar, que es el morir; allí van los señoríos

103. Francisco de Andrada es un poeta portugués e historiador de la segunda mitad del siglo XVI y comienzos del XVII.

104.- Como historiador, Andrada es autor de Chronica do muito alto e poderoso rey destos Reinos de Postugal, Don Joao III, (1613). 


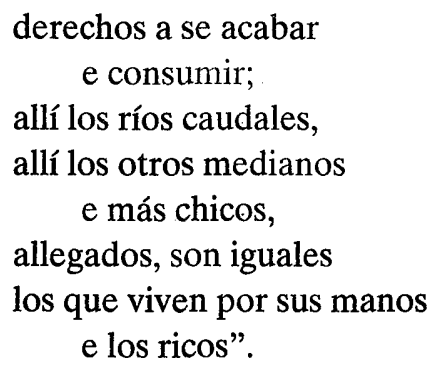

Mas no se crea que fue fácil el conseguir se comenzara a usar la lengua romance en los libros de piedad y de doctrina espiritual. Uno de los grandes campeones en esta buena lid fue, sin duda alguna, el Mtro. Fray Luis de León, el cual escribió en su inmortal De los Nombres de Cristo lo siguiente: "Es engaño común tener por fácil y de poca estima todo lo que se escribe en romance; que ha nacido o de lo mal que usamos de nuestra lengua, no la empleando sino en cosas sin ser, o de lo poco que entendemos de ella, creyendo que no es capaz de lo que es de importancia: que lo uno es vicio y lo otro engaño, y todo ello falta nuestra, y no de la lengua ni de los que se esfuerzan a poner en ella todo lo grave y precioso que en algunas de las otras se halla.

Así que no piensen, porque ven en romance, que es de poca estima lo que se dice; mas, al revés, viendo lo que se dice, juzguen que puede ser de mucha estima lo que se escribe en romance, y no desprecien por la lengua las cosas, sino por ellas estimen la lengua, si acaso las vieron; porque es mucho de creer que los que esto dicen, no las han visto ni leído" ${ }^{105}$.

No era culpa, pues, de los que se esforzaban en poner en la lengua vernácula "todo lo grave y precioso" que encontraban en otras. Uno de ellos, nuestro Fray Alonso de Orozco. El que fuera arzobispo de Valladolid, cardenal Sanz y Forés, en un discurso que pronunció con motivo de la beatificación del siervo de Dios, decía lo siguiente: "Es la lengua vivo espejo donde se retrata la cultura, genialidad y vicisitudes todas de un pueblo; para lo cual no obsta la variación y mudanza de sus voces, como para retratar la hermosura de las riberas no es estorbo a las cristalinas aguas de los ríos su continuo cambio y deslizamiento. Digo más: que el rostro de los pueblos ha de ser por fuerza su lengua; porque en ésta únicamente cabe la expresión de sus agitaciones y el cabal deleite de su vida. Inmortalizarán acaso sus hazañas heroicas naciones en brillantes rasgos de la historia, en soberbios monumentos

105. LeÓn, F. Lurs DE, De los Nombres de Cristo. Dedicatoria a don Pedro Portocarrero. Ed. BAC, Madrid 1944, III, p. 672. 
desafiadores de los siglos; pero la inmortalidad será solamente de recuerdo, manifestando el heroísmo que pasó; su existencia actual y vivir perenne es indudable que se muestra sólo en el movimiento, colorido y fecundación de su lengua" ${ }^{106}$.

Más adelante, el ilustre purpurado añadiría que al Beato Alonso de Orozco le cupo el honor de haber sido "el primer apologista de la lengua española", antes de que lo hicieran de modo tan contundente y claro el citado Mtro. León, Malón de Chaide y Fray Cristóbal de Fonseca; el primero de ellos, autor de su famoso libro Conversión de la Magdalena, y el segundo, de la obra titulada Tratado del amor de Dios, del que escribiría Lope de Vega:

"Fonseca universal 'uente perenne, ya no Fonseca, sino fuente viva, pues en admiración el mundo tiene tu misma pluma, tu alabanza escriba".

Precisamente, este agustino, saliendo, en el prólogo de su libro, en defensa de la lengua vernácula, dice: "Una sola cosa quiero decir al lector, que si este libro fuere bien recibido, dándome Dios algunos años de vida $\mathrm{y}$ salud, prometo muchos de materias varias: y atrévome a hacer tan larga promesa, favoreciéndome el cielo, por el poco trabajo que éste me ha costado, y por el breve tiempo en que le he compuesto" ${ }^{107}$.

Aún no había surgido san Juan de la Cruz, del que dirá don Marcelino Menéndez Pelayo que su poesía no es de hombres, sino de ángeles; santa Teresa de Jesús vivía aún en la oscuridad, y el Mtro. León comenzaba a ofrecer la galanura de su lenguaje, cuando el de Oropesa de Toledo, heredero del espíritu de Santo Tomás de Villanueva, y del Venerable Fray Luis de Montoya, declaraba su doctrina religiosa, ascética y mística en brillantes períodos del habla castellana. Él fue el primero en levantarla de los hogares y salas domésticas, de las calles y plazas, de la poesía lírica de Garcilaso de la Vega y de la sonora prosa de Antonio de Guevara a la altura y cumbre de un decir profundo y, al mismo tiempo, bello con doctrina ascética y mística, dando a luz libros tan armoniosos y clásicos como los citados arriba.

Pensemos que Vergel de oración y Monte de contemplación, y Memorial de amor Santo fueron publicados justamente a mediados del siglo XVI; lo que hace mucho más meritorio el estilo castizo y elevado de Fray Alonso de Orozco, aparte su atrevimiento de presentar el contenido espiritual de estas

106. SANZ y Forés, B., Discurso..., Velada literaria, l.c., p. 13.

107. FonsecA, C. de, Tratado del Amor de Dios. Ed. Imp. de Guillermo Foquel, Salamanca 1592. Prólogo. 
obras en lengua romance. Un estilo y un lenguaje que irán perfeccionándose con nuevos matices de flexión y de armonía en las innumerables obras que van a seguir a estas dos joyas de la literatura religiosa española, hasta prácticamente el año 1591 -año de su muerte-, toda vez que nunca descansó su pluma, ni siquiera cuando estaba postrado en el lecho del dolor.

Es verdad que no ha tenido suerte el P. Orozco entre los críticos y entendidos de la materia, si bien su nombre figura entre las Autoridades de la Lengua. Es posible que la causa sea debida a la ignorancia de sus muchos y valiosos escritos que compuso en la que luego se va a llamar "lengua de Cervantes". Atrás queda citado Ticknor y su traductor Gayangos. Pero son todavía más imperdonables hombres como don José Amador de los Ríos ${ }^{108}$, catedrático de literatura española en la Universidad de Madrid y autor, entre otros libros, de una Historia crítica de la literatura española, el cual tampoco tuvo presente los escritos más selectos de nuestro agustino, como autor clásico y autoridad indiscutible de la Lengua, y que por ventura solamente había leído por encima el libro de las Confesiones, en el que -según declara don Amador de los Ríos- "revela las vacilaciones de su espíritu y las místicas visiones que le conturbaban y fortalecían, sin dejar de logar en sus calurosos apóstrofes el tono de la verdadera elocuencia" ${ }^{109}$.

Cuando el P. Juan Márquez -"luz del siglo XVI y gloria de la Religión de san Agustín", en expresión de Tomás Herrera, se ponga a escribir una biografía del P. Alonso de Orozco ${ }^{110}$, dirá sobre el tema que nos ocupa que "era agudo en las sentencias, propio en las palabras, suave en el estilo, casto en las frases, no forzado en las metáforas y nada inferior en romance y latín a los que con mayor primor escriben en una y en otra lengua".

Es posible que, como dice acertadamente Sanz y Forés, no se vea en los escritos de Orozco la pompa y artificio de Fray Luis de Granada, el número y compás del Mtro. León, la traza y el punto de Fray Cristóbal de Fonseca, todos ellos contemporáneos del asceta y místico agustino, pero se aspira

108. Don José Amador de los Ríos, nacido en la ciudad andaluza de Baena, se inició como escritor en estudios históricos, que fue publicando en el "Semanario pintoresco español". Catedrático luego de literatura en la Universidad de Madrid, es autor de Historia política, social y religiosa de los judios en España y Portugal. Pero quizá le haya dado más fama su libro titulado Historia crítica de la literatura española, la cual supuso un notable avance en los estudios literarios de nuestra patria, tanto por los datos recogidos, como por la aportación original sobre la literatura medieval.

109. AMAdOR De los Ríos, J., Historia crítica de la literatura española, Madrid 1865, vol. VII, p. 354.

110. La expresión se la debemos a Tomás de Herrera; y lo dice a propósito de las dos grandes obras que escribió el P. Juan Márquez, dentro todavía del siglo de oro español: Los dos Estados de la espiritual Jerusalén, y El Gobernador cristiano. 
"deleitoso aroma de suavidad e inexplicable ternura de afectos que saben a gloria".

"Que saben a gloria". ¡Qué bien dicho y qué bien suena aquí! Los libros del Beato Alonso de Orozco saben a gloria. Y es que nacieron al calor de un alma abrasada en el amor divino, llevada del sentimiento y de la inspiración. Son como flores espontáneas, donde apenas se echa de ver la mano del hombre. Por eso, no habiéndose hecho violencia su autor, salieron todos ellos vivo retrato de su carácter llano, modesto y apacible.

A sus setenta y dos años publicaba un libro titulado Suavidad de Dios ${ }^{111}$. Un libro que dedicaba, con un afecto y una ternura entrañables a la reina doña Ana de Austria, madre de Felipe III y cuarta esposa del rey Felipe II. Un libro de contenido fecundo para un fino amante de Dios y de las cosas divinas. En él, su autor se eleva hasta casi tocar las riberas de la patria celestial; y vislumbrando ya "las riquezas y deleites" que allí se han de gozar, trata de explicárselas a los hombres "por manera suavísima y encantadora".

"El buen cristiano, cumpliendo la voluntad de Dios -escribe Orozco en un bellísimo castellano-, tiene paz en su conciencia, vive alegre y es muy favorecido cada momento de la gracia que Dios le comunica. Ayúdanle los ángeles y favorécenle los justos con sus oraciones y ejemplos buenos. Así lo confiesa el profeta David y con breves palabras. En el camino de tus mandamientos, Señor, me deleité, así como con todas las riquezas del mundo. Éste es el camino que aquellos desventurados ignoraron, camino llano, floresta apacible y paraíso en la tierra, del cual solamente gozan los amigos de Dios; pues, como los pecadores van tan perdidos por los montes y desiertos trabajosos de sus pasiones, se olvidan'.de su cama. ¡Oh cama de reposo! Cama florida y llena de todo descanso; descansadero de todos los afligidos, Cristo, Señor nuestro!" ${ }^{112}$.

Hoy, en que tanto se ha deteriorado nuestro idioma con las expresiones que nos han venido de fuera y las desafortunadas que nos han inventado algunos políticos de pacotilla, resulta consolador leer a escritores como Fray Alonso de Orozco, Luis de León, Malón de Chaide, Cristóbal de Fonseca..., todos ellos anteriores a Cervantes, a Quevedo y Lope de Vega, pero ya del todo clásicos y castizos de la lengua castellana.

Tenía ochenta y dos años de edad y el "santo de San Felipe", comentando la frase evangélica, puesta en boca de Pedro: "Señor, qué bueno es estarnos aquí", refiriéndose a la transfiguración en el Monte Tabor, escribe:

111. Orozco, A. de, Libro de la suavidad de Dios. Imp. Simón de Portonaris, Salamanca, 1576.

112. Ibid., l.c., cap. XXIV. 
"Teniéndoos a Vos, Criador nuestro, presente, este monte, que parece soledad, nos será vergel deleitoso; las chozas que haremos de los ramos de estos árboles, tendremos en más que ricos palacios reales. Cuando lloviere y nos mojáremos, será rocío de agua de ángeles. Finalmente, si el sol con su calor nos diere alguna pesadumbre, con mirar ese rosttro divino, a quien desean mirar los ángeles, tendremos regalado refrigerio" ${ }^{113}$.

"Varón santo y hombre de doctrina insigne", le llamó el General de la Orden Rmo. P. Gregorio Petrocchini, después de oirle predicar un sermón en la iglesia del convento de san Agustín de Toledo en 1589, es decir, dos años antes de su muerte. Y mandó que estas palabras, puestas en lengua latina, se copiaran en los Registros de la Orden ${ }^{114}$.

Doña Beatriz de Freita, dama de honor de la reina doña Ana de Austria, que tuvo la suerte de escuchar muchas veces en palacio al P. Orozco, dice que sus sermones eran de mucha eficacia, "porque predicaba como varón apostólico, sin artificio y con mucha simplicidad de palabras, con gran fervor y afecto de aprovechar las almas; porque a todos era notoria su vida y santidad y gran caridad que tenía con los pobres" ${ }^{115}$.

El autor de Místicos Agustinos españoles, Ignacio Monasterio Codina, no tiene reparo alguno en afirmar que el Beato Alonso de Orozco es "nuestra más relevante figura como escritor místico y ascético". ¿Exageraba el docto agustino asturiano?... Tal vez. Pero nadie debe poner en duda al que estamos en presencia de uno de los grandes escritores clásicos españoles en esta materia tan delicada como profunda. Monasterio destaca el momento histórico en que el Venerable se revela como autor místico "de los más importantes en todo el siglo XVI, en los reinados de Carlos V y Felipe II", cuando España llegaba al apogeo de su gloria política, militar, literaria y religiosa.

En este sentido, el P. Orozco, cronológicamente hablando, pertenece a dos períodos en que, según Menéndez Pelayo, se divide la historia de la ciencia mística española. El primero, que lo considera de formación, y que no va más allá del 1550, conoció a escritores de la talla de Juan de Ávila, Luis de Montoya, Alonso de Madrid, Francisco de Osuna y Bernardino de Laredo. El segundo período, para el gran polígrafo montañés, es el que merece ser llamado con toda propiedad y plenamente de oro, pues en él se escribieron

113. Orozco, A. de, Guarda de la lengua. Imp. Pedro Madrigal, Madrid 1589, cap. XX.

114. Gutiérrez, D., Historia de la Orden de San Agustín, vol. II, cap. VI, p. 178. Ed. Institutum Historicum Ordinis Fratrum S. Augustini, Roma 1971.

115. Palabras recogidas en el Informe Sumarial de Madrid, fol. 53. 
la mayor y más importantes obras, debidas a los dos Luises, a Teresa de Jesús y Juan de la Cruz, entre otros.

Nada de extraño tiene, pues, que, al tiempo de presentar los escritos de nuestro agustino los postuladores de la causa de su beatificación, para defensa de los mismos, se atrevieran a pedir al Sumo Pontífice que lo admitiera entre el número de los Doctores de la Iglesia.

No le cupo ese honor; como tampoco le cupo a su maestro y superior santo Tomás de Villanueva; pero nadie dudará actualmente de que uno y otro se lo tienen bien merecido; tal vez mucho mejor y con más méritos que algunos doctores, a los que se lo han concedido recientemente, a juzgar por los escritos que nos han dejado.

Teófilo APARICIO LÓPEZ 